\title{
Three-Dimensionally Porous Li-Ion and Li-S Battery Cathodes: A Mini Review for Preparation Methods and Energy-Storage Performance
}

\author{
Jinyun Liu ${ }^{1, *}$, Jiawei Long ${ }^{1}{ }^{1}$, Sen $\mathrm{Du}^{2}$, Bai Sun ${ }^{3}$, Shuguang $\mathrm{Zhu}^{3}$ and Jinjin $\mathrm{Li}^{2}{ }^{2 *}$ \\ 1 Key Laboratory of Functional Molecular Solids, Ministry of Education, College of Chemistry and Materials \\ Science, Anhui Normal University, Wuhu 241002, China; jwlong@ahnu.edu.cn \\ 2 Key Laboratory for Thin Film and Micro Fabrication, Ministry of Education, Department of Micro/Nano \\ Electronics, Shanghai Jiao Tong University, Shanghai 200240,China; du_sen@sjtu.edu.cn \\ 3 Department of Environmental Engineering, College of Environment and Energy Engineering, \\ Anhui Jianzhu University, Hefei 230601, China; bsun@mail.ustc.edu.cn (B.S.); \\ zhushuguang@ahjzu.edu.cn (S.Z.) \\ * Correspondence: jyliu@ahnu.edu.cn (J.L.); lijinjin@sjtu.edu.cn (J.L.)
}

Received: 9 February 2019; Accepted: 11 March 2019; Published: 15 March 2019

\begin{abstract}
Among many types of batteries, Li-ion and Li-S batteries have been of great interest because of their high energy density, low self-discharge, and non-memory effect, among other aspects. Emerging applications require batteries with higher performance factors, such as capacity and cycling life, which have motivated many research efforts on constructing high-performance anode and cathode materials. Herein, recent research about cathode materials are particularly focused on. Low electron and ion conductivities and poor electrode stability remain great challenges. Three-dimensional (3D) porous nanostructures commonly exhibit unique properties, such as good $\mathrm{Li}^{+}$ion diffusion, short electron transfer pathway, robust mechanical strength, and sufficient space for volume change accommodation during charge/discharge, which make them promising for high-performance cathodes in batteries. A comprehensive summary about some cutting-edge investigations of $\mathrm{Li}$-ion and Li-S battery cathodes is presented. As demonstrative examples, $\mathrm{LiCoO}_{2}$, $\mathrm{LiMn}_{2} \mathrm{O}_{4}, \mathrm{LiFePO}_{4}, \mathrm{~V}_{2} \mathrm{O}_{5}$, and $\mathrm{LiNi}_{1-\mathrm{x}-\mathrm{y}} \mathrm{Co}_{\mathrm{x}} \mathrm{Mn}_{\mathrm{y}} \mathrm{O}_{2}$ in pristine and modified forms with a $3 \mathrm{D}$ porous structure for $\mathrm{Li}$-ion batteries are introduced, with a particular focus on their preparation methods. Additionally, S loaded on 3D scaffolds for Li-S batteries is discussed. In addition, the main challenges and potential directions for next generation cathodes have been indicated, which would be beneficial to researchers and engineers developing high-performance electrodes for advanced secondary batteries.
\end{abstract}

Keywords: secondary battery; nanostructure; porosity; capacity; stability

\section{Introduction}

Rechargeable batteries are widely used in emergency power backup, electric vehicles, solar power storage, portable equipment, and wearable electronics [1,2]. Among them, Li-ion and Li-S batteries have competitive advantages to the others [3-9]. The principle of Li-ion batteries is the insertion and extraction of Li ions in the electrodes during charge and discharge [10-13], as illustrated in Figure 1. The electricity outside the battery is carried by electrons around the external circuit in the opposite direction to Li ions. For Li-S batteries, as displayed in Figure 2, $\mathrm{S}_{8}$ reacts with $\mathrm{Li}$ ions to form high-order lithium polysulfides $\mathrm{Li}_{2} \mathrm{~S}_{\mathrm{x}}(4<\mathrm{x}<8)$, and then lower-order lithium polysulfides $\mathrm{Li}_{2} \mathrm{~S}_{\mathrm{x}}(2<\mathrm{x}<4)$ are formed as the Li ions insert continuously [14-16]. 
Currently, cathode materials are one of the key points for the development of high-performance Li-ion batteries and Li-S batteries [17,18]. Many cathode materials, almost with porous characteristics, have the advantages of enlarged surface area, increased specific capacity, and are able to overcome volume variation. Among various structures, three-dimensional (3D) porous structures are considered ideal and promising.

It is necessary to improve the kinetics of the extraction/insertion process of $\mathrm{Li}$ ion in $\mathrm{Li}$-ion batteries and the reaction between $\mathrm{Li}$ ions and $\mathrm{S}$ in Li-S batteries, which can be facilitated by constructing a 3D porous morphology. In addition, 3D porous structures have several void spaces, which are able to improve the contact with electrolytes. However, a part of the electrolyte is needed to wet the active materials during the charge/discharge process, therefore the 3D structure would consume more electrolytes [19-21]. In addition, the reduced material loading within the 3D electrode also needs to be improved for practical applications. Both the advantages and drawbacks of the 3D porous electrodes make it an attractive field for intensive study. Herein, we focus on the 3D porous cathode materials used in both Li-ion and Li-S batteries and their preparation methods.

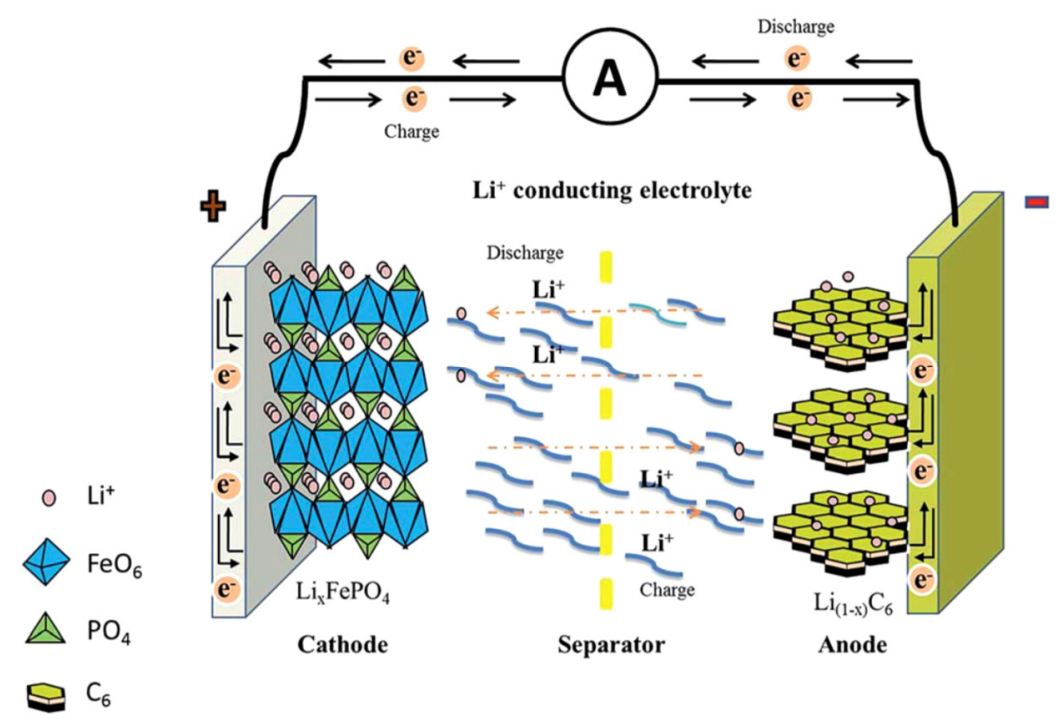

Figure 1. Schematic illustration for the working mechanism of a typical $\mathrm{LiFePO}_{4}$ cathode-based $\mathrm{Li}$-ion battery. Reproduced with permission from [12]. The Royal Society of Chemistry, 2014.
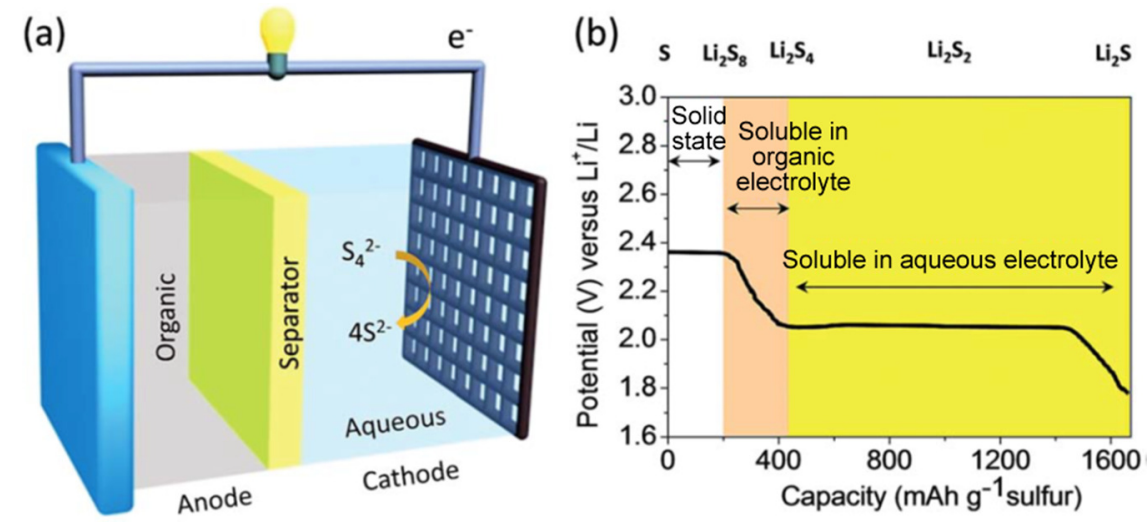

Figure 2. (a) Illustration of a Li-S battery and the (b) electrochemical species formed during lithiation. Reproduced with permission from [14]. The Royal Society of Chemistry, 2015.

\section{Challenges of Li-Ion and Li-S Battery Cathodes}

Performances of Li-ion batteries are partly dependent on the intrinsic property of the materials used in the cathodes. For cathode materials, high specific capacity, high potential, large ionic and 
electronic transport rate, and long life are preferred. Nowadays, most of the cathode materials are $\mathrm{Li}$-based intercalation compounds. The available compounds, such as $\mathrm{LiNiO}_{2}, \mathrm{LiCoO}_{2}$, and $\mathrm{LiMnO}_{2}$, are investigated for cathode applications. To achieve a high energy-density, some compounds composed of multiple metal atoms, such as $\mathrm{LiNi}_{1 / 3} \mathrm{Co}_{1 / 3} \mathrm{Mn}_{1 / 3} \mathrm{O}_{2}(\mathrm{NCM})$, are expected to replace part of the single metal compounds [22]. Compounds with $\mathrm{MO}_{6}$ octahedra (where $\mathrm{M}$ is $\mathrm{Fe}, \mathrm{Mg}$, or $\mathrm{V}$ ) and $\mathrm{XO}_{4} \mathrm{n}$ - tetrahedral anions (where $\mathrm{X}$ is $\mathrm{Si}$ or $\mathrm{P}$ ) are of interest because these structures can tune transition metal redox potentials, such as $\mathrm{Fe}^{3+} / \mathrm{Fe}^{2+}$. However, these kinds of compounds have a common and fundamental problem in that the conductivity is poor, which reduces the electrochemical performance.

Compared to Li-ion batteries, Li-S batteries have a much higher theoretical energy density $\left(2600 \mathrm{Wh} \mathrm{kg}^{-1}\right)$ and better capacity $\left(1672 \mathrm{mAh} \mathrm{g}^{-1}\right)$ [23]. However, severe issues of sulfur need to be addressed. At first, elemental sulfur is a natural insulator $\left(5 \times 10^{-30} \mathrm{~S} \mathrm{~cm}^{-1}\right)$, which absolutely restricts the movements of electrons. The long-chain lithium polysulfide formed during the discharge process tends to dissolve in the organic electrolytes. When these polysulfides diffuse to the anode through the electrolytes, and react with the lithium anode, the reactions are named as shuttle mechanisms. During the transition between long-chain and short-chain lithium polysulfides, partial electrical energy is consumed and this unexpected phenomenon restricts the electrical efficiency. Meanwhile, an unstable film will be generated because of such uncontrolled reactions. As a result, the instability of solid electrolyte interface (SEI) film has a negative effect on the cycling stability of Li-S batteries. It is mentioned that the mass density of sulfur $\left(2.03 \mathrm{~g} \mathrm{~cm}^{-3}\right)$ is about $20 \%$ larger than that of $\mathrm{Li}_{2} \mathrm{~S}(1.67 \mathrm{~g}$ $\mathrm{cm}^{-3}$ ), which causes the non-ignorable shrink and expansion during charge and discharge. Last but not least, the morphology of the lithium electrode is changeable due to the deposition of lithium ions from electrolytes. Dendrites of lithium growing on the surface of the electrode should be removed to ensure battery safety.

\section{Methods for Making 3D Porous Li-Ion Battery Cathodes}

\subsection{Hydrothermal Synthesis}

Hydrothermal methods include the various techniques for crystallizing materials from high-temperature aqueous solutions at high vapor pressures. Compared with several other types of crystal growth, the hydrothermal approach is able to create crystalline phases that are not stable at the melting point. In addition, materials that have a high vapor pressure near their melting points can be grown by the hydrothermal method. These advantages make the hydrothermal method suitable for constructing many 3D electrodes for batteries. This section will mainly focus on the hydrothermal methods.

The conventional $\mathrm{LiFePO}_{4}$ cathode has a poor electronic conductivity $\left(\sim 10^{-9} \mathrm{~S} \mathrm{~cm}^{-1}\right)$ and slow lithium ion diffusion, which restricts its wide application [24]. Several methods have been performed to enhance the electric conductivity and the rate of ion transport, including reducing the size of $\mathrm{LiFePO}_{4}$ to the nanometer scale, coating particles with conductive materials, or expanding surface areas through structure manufacture. A 3D current collector of carbon layer coated $\mathrm{LiFePO}_{4}$ was constructed, in order to improve the high-rate discharge capacity compared to conventional cells using the foil current collector. Furthermore, the carbon layer on $\mathrm{LiFePO}_{4}$ nanoparticles with a diameter between $70 \mathrm{~nm}$ and $100 \mathrm{~nm}$ protects these particles and also contributes to conductivity enhancement [25]. In addition, the porous substrates made of nickel and chromium not only improve electric conductivity but also produce a large surface area.

$\mathrm{Du}$ et al. reported a facile in situ one-pot hydrothermal method for preparing a conductive graphene (G)/ $\mathrm{LiFePO}_{4}$ composite [26]. When $\mathrm{LiFePO}_{4}$ nanoparticles load on the 3D graphene network, rapid electronic transmission and a short lithium ion transfer pathway can be achieved. The 3D $\mathrm{G} / \mathrm{LiFePO}_{4}$ composite exhibited a high capacity of $160 \mathrm{mAh} \mathrm{g}^{-1}$ at $0.2 \mathrm{C}(94.12 \%$ of its theoretical capacity of $\left.170 \mathrm{mAh} \mathrm{g}^{-1}\right)$, a good rate performance of $115 \mathrm{mAh} \mathrm{g}^{-1}$ at $10 \mathrm{C}$ (71.9\% of its initial capacity), 
and good cycling performance of $94.2 \%$ capacity retention after 100 cycles, all of which imply their potential application in high rate Li-ion batteries.

Fu et al. [27] presented a novel hollow hierarchical structured composite of $0.5 \mathrm{Li}_{2} \mathrm{MnO}_{3} \cdot 0.5 \mathrm{LiMn}_{0.4}$ $\mathrm{Co}_{0.3} \mathrm{Ni}_{0.3} \mathrm{O}_{2}$ with a flower-like morphology. The presence of the internal cavity in the nanoplates, which consist of the complete flower-like composites, indicates that the hollow shell can provide channels for electrolytes and ions. The discharge capacities are 296.5, 270.6, 243.6, 207.8, and 187.4 mAh $\mathrm{g}^{-1}$ at rates of $0.2,0.5,1,3$, and $5 \mathrm{C}$, respectively. The capacity retention is over $87 \%$ after 100 cycles at $0.5 \mathrm{C}$ with a capacity fading rate of $0.13 \%$ per cycle.

$\mathrm{Li}_{3} \mathrm{~V}_{2}\left(\mathrm{PO}_{4}\right)_{3}$, with the crystal structure of monocline, is promising for the cathode material in $\mathrm{Li}$-ion batteries because of its inherent characteristics of a high working potential of $4.8 \mathrm{~V}$, theoretical capacity of $197 \mathrm{mAh} \mathrm{g}^{-1}$, and higher energy density of $800 \mathrm{Wh} \mathrm{kg}^{-1}$ [28]. $\mathrm{Li}_{3} \mathrm{~V}_{2}\left(\mathrm{PO}_{4}\right)_{3}$ phase consists of a 3D framework of slightly distorted $\mathrm{VO}_{6}$ octahedra- and $\mathrm{PO}_{4}$ tetrahedra-sharing oxygen vertexes, which host $\mathrm{Li}$ ions in relatively large interstitial sites, leading to fast ionic transport. Cui et al. prepared carbon-coated $\mathrm{Li}_{3} \mathrm{~V}_{2}\left(\mathrm{PO}_{4}\right)_{3}$ nanocrystals that were modified by graphene nanosheets and carbon nanotubes through a hydrothermal method [29], as shown in Figure 3. The graphene nanosheets and the carbon nanotubes are interconnected to form a 3D conductive network, which also support $\mathrm{Li}_{3} \mathrm{~V}_{2}\left(\mathrm{PO}_{4}\right)_{3}$ particles. When using graphene sheets, the aggregated $\mathrm{Li}_{3} \mathrm{~V}_{2}\left(\mathrm{PO}_{4}\right)_{3} / \mathrm{C}$ nanoparticles load on graphene sheets, forming a 3D layered structure. When the carbon nanotubes were also used, the interconnection between each graphene layer was improved. The carbon nanotubes enhance the structure strength and provide pathways for electron transfer. Considering the shaggy structure of the composites (Figure 4), the composite exhibits a remarkably high rate capability and long cycle stability. An initial discharge capacity of $147.5 \mathrm{mAh} \mathrm{g}^{-1}$ at $20 \mathrm{C}$ at a potential range of $3.0-4.8 \mathrm{~V}$ is obtained. The capacity retention is $82.7 \%$ after 2000 cycles.

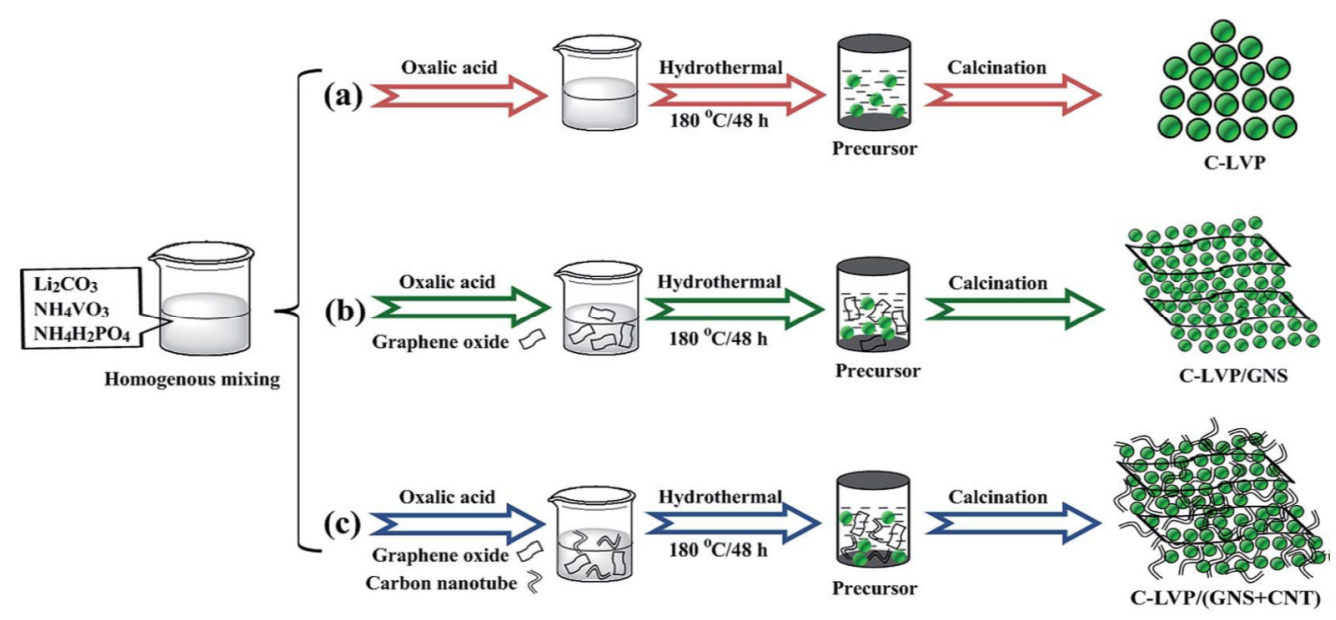

Figure 3. Schematic illustration of preparing nanosized $\mathrm{Li}_{3} \mathrm{~V}_{2}\left(\mathrm{PO}_{4}\right)_{3} / \mathrm{C}$ (C-LVP), carbon nanotube modified $\mathrm{Li}_{3} \mathrm{~V}_{2}\left(\mathrm{PO}_{4}\right)_{3} / \mathrm{C}$ (C-LVP/GNS), graphene nanosheet, and carbon nanotube co-modified $\mathrm{Li}_{3} \mathrm{~V}_{2}\left(\mathrm{PO}_{4}\right)_{3} / \mathrm{C}(\mathrm{C}-\mathrm{LVP} /(\mathrm{GNS}+\mathrm{CNT}))$ composites via a hydrothermal-assisted sol-gel route. Reproduced with permission from [29]. The Royal Society of Chemistry, 2016.

Vanadium pentoxide $\left(\mathrm{V}_{2} \mathrm{O}_{5}\right)$ is a typical intercalation compound. It possesses a layered structure that can accept more than one electron and lithium ion through the reaction $\mathrm{V}_{2} \mathrm{O}_{5}+\mathrm{xLi}^{+}+\mathrm{xe}^{-} \leftrightarrow$ $\mathrm{Li}_{\mathrm{x}} \mathrm{V}_{2} \mathrm{O}_{5}$. However, $\mathrm{V}_{2} \mathrm{O}_{5}$ has shortcomings, with a moderate electrical conductivity of $10^{-4}-10^{-5} \mathrm{~S}$ $\mathrm{cm}^{-1}$ and low $\mathrm{Li}^{+}$diffusion coefficient of $10^{-12} \mathrm{~cm}^{2} \mathrm{~s}^{-1}$ [30]. As is known, binder-free technology loads active materials on the current collector without any binders and conductive adhesives, enabling a simplified electrode for batteries. Many free-standing $3 \mathrm{D}$ porous $\mathrm{V}_{2} \mathrm{O}_{5}$ electrodes have been reported. For example, Gao et al. reported a one-step hydrothermal method to confine vanadium pentoxide particles in 3D N-doped graphene as a free-standing cathode [31]. The good conductivity and elastic properties of $\mathrm{N}$-doped graphene are utilized efficiently. The composite cathode shows a high capacity 
of $283 \mathrm{mAh} \mathrm{g}^{-1}$ at $100 \mathrm{~mA} \mathrm{~g}^{-1}\left(96.3 \%\right.$ of its theoretical capacity of $\left.294 \mathrm{mAh} \mathrm{g}^{-1}\right)$ and a good rate performance of $134 \mathrm{~mA} \mathrm{~g}^{-1}$ at $1 \mathrm{~A} \mathrm{~g}^{-1}$ (78\% of its initial capacity).

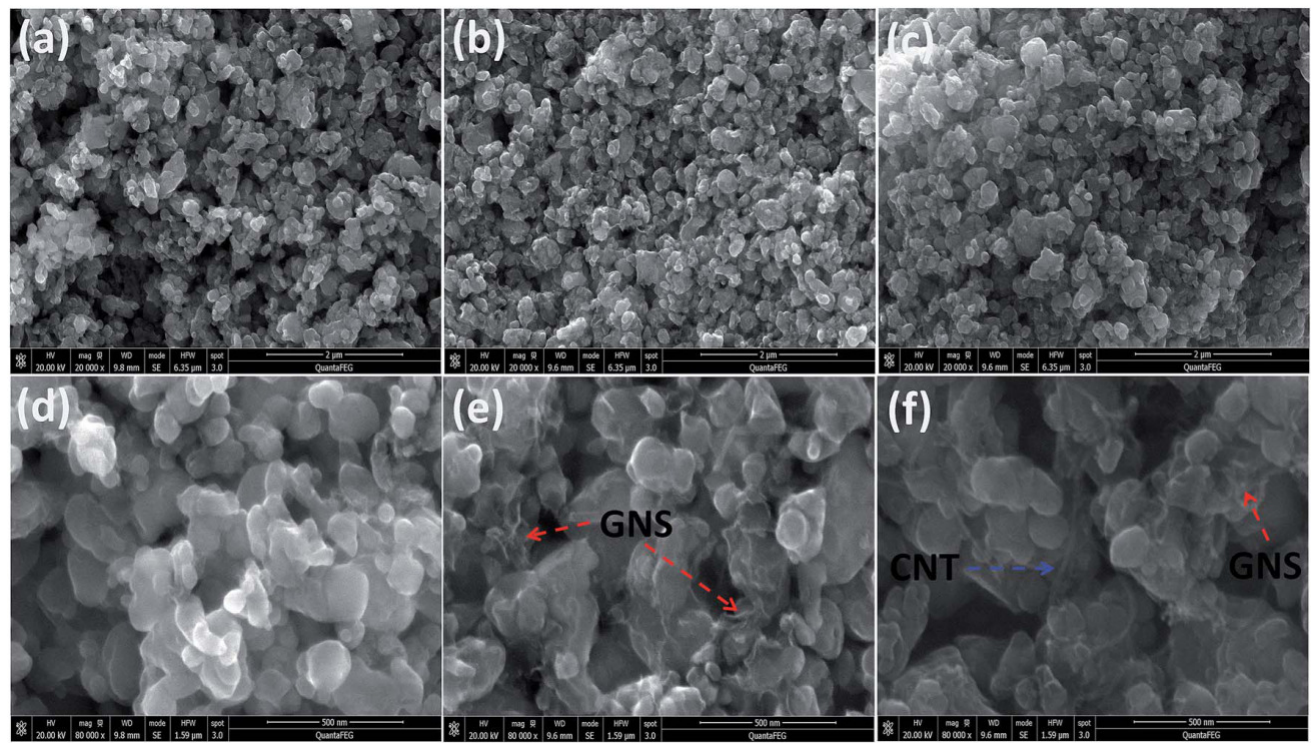

Figure 4. Scanning electron microscopy (SEM) images of (a,d) C-LVP, (b,e) C-LVP/GNS, and (c,f) C-LVP/(GNS+CNT). Reproduced with permission from [29]. The Royal Society of Chemistry, 2016.

In addition, 3D hierarchical nanostructures are widely applied in electrodes because such structures suppress the agglomeration and improve the diffusion of lithium ions. Pan et al. found that the precursor of vanadyl oxalate $\left(\mathrm{VOC}_{2} \mathrm{O}_{4}\right)$ at different concentrations impacts on the morphology of the products [32]. As seen in Figure 5, they reported a facile solvothermal method to produce hierarchical nano and microstructures of vanadium oxide by adjusting the concentration of $\mathrm{VOC}_{2} \mathrm{O}_{4}$ and the duration time. Urchin-like $\mathrm{VO}_{2}$ microflowers were first synthesized without surfactants through self-assembly, which were followed by calcination to transform $\mathrm{VO}_{2}$ into urchin-like $\mathrm{V}_{2} \mathrm{O}_{5}$ microstructures. The $\mathrm{V}_{2} \mathrm{O}_{5}$ microstructures were composed of nanobelts and nanorods, in which a highly porous texture was confirmed. The obtained $\mathrm{V}_{2} \mathrm{O}_{5}$ had a specific area of $33.64 \mathrm{~m}^{2} \mathrm{~g}^{-1}$, which is ascribed to the 3D hierarchical porous structure and the large surface area of the building blocks. In addition, when evaluated as a cathode material, the $\mathrm{V}_{2} \mathrm{O}_{5}$ cathode delivers a high specific discharge capacity of $267 \mathrm{mAh} \mathrm{g}^{-1}$ at a current density of $300 \mathrm{mAh} \mathrm{g}^{-1}$.

Guo et al. reported a simple hydrothermal method for the synthesis of a fine $\mathrm{V}_{2} \mathrm{O}_{5}-\mathrm{SnO}_{2} / \mathrm{CNTs}$ composite, in which the nanosized $\mathrm{V}_{2} \mathrm{O}_{5}$ coating and the carbon nanotubes (CNTs) were connected through $\mathrm{SnO}_{2}$ nanoparticles [33]. After heat treatment, the composites were verified to be porous due to the stack of CNTs. The external surface of the CNTs was uniformly covered with $\mathrm{SnO}_{2}$ and $\mathrm{V}_{2} \mathrm{O}_{5}$, which improved the cyclic capacity and the rate capacity as a result of the excellent conductivity. The $\mathrm{V}_{2} \mathrm{O}_{5}-\mathrm{SnO}_{2} / \mathrm{CNTs}$ composite cathode exhibited an initial discharge capacity of $250 \mathrm{mAh} \mathrm{g} \mathrm{g}^{-1}$ from 2.05 to 4.0 V. Furthermore, a high coulombic efficiency (over 99\%) for all cycles was achieved, which showed an excellent cycling stability.

Our group has presented a facile method for manufacturing 3D structural electrodes by integrating active materials and graphene [34]. As displayed in Figure 6, a sandwich-like structure of $\mathrm{V}_{2} \mathrm{O}_{5} @$ graphene@ $\mathrm{V}_{2} \mathrm{O}_{5}$ was fabricated for the cathode based on the 3D inverse opal template. At first, a Ni inverse opal was electrodeposited on a polystyrene opal template, on which graphene was then grown via chemical vapor deposition. After a $\mathrm{Ni}$ etching process, a layer of $\mathrm{V}_{2} \mathrm{O}_{5}$ was grown onto the external surface of graphene. Then, another layer of $\mathrm{V}_{2} \mathrm{O}_{5}$ was grown into the inner layer of graphene, forming the 3D $\mathrm{V}_{2} \mathrm{O}_{5} @$ graphene@ $@ \mathrm{~V}_{2} \mathrm{O}_{5}$ composite. The cathode provided a full electrode 
basis capacity of about $230 \mathrm{mAh} \mathrm{g}^{-1}$ at $5 \mathrm{C}$ after 200 cycles, and $203 \mathrm{mAh} \mathrm{g}^{-1}$ after 2000 cycles, along with a Coulombic efficiency of $99.7 \%$.

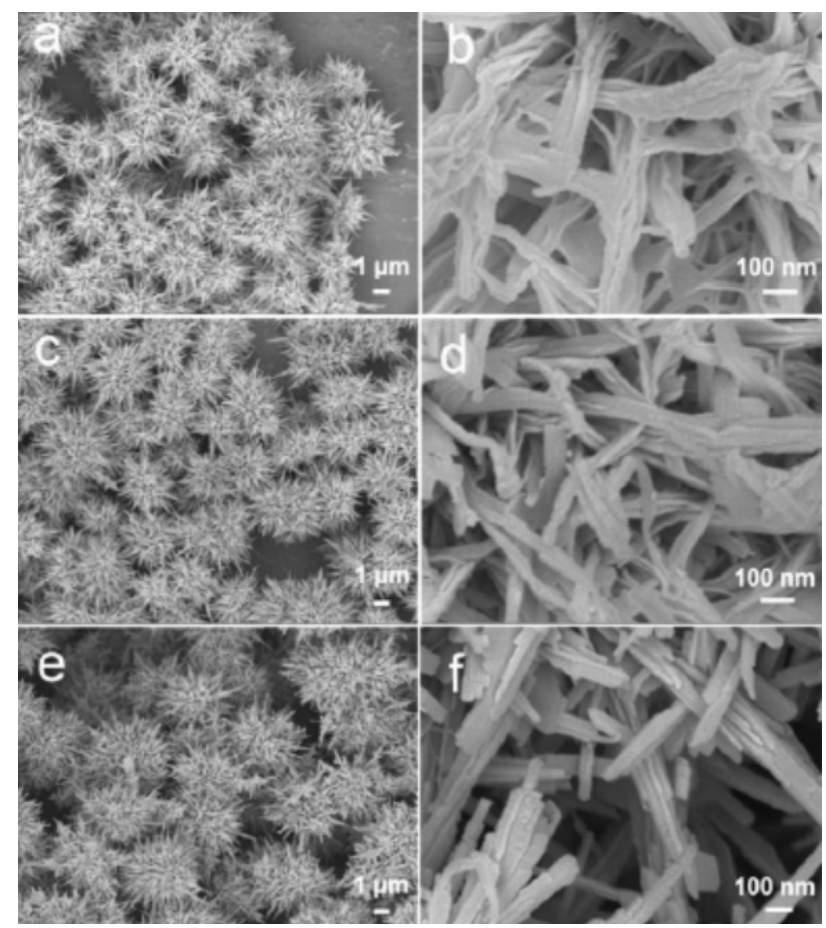

Figure 5. SEM images of the 3D vanadium oxide obtained after different solvothermal reaction time: $(\mathbf{a}, \mathbf{b})$ VO-0.5 h, (c,d) VO-2 h, and (e,f) VO-24 h. Reproduced with permission from [32]. American Chemical Society, 2012.

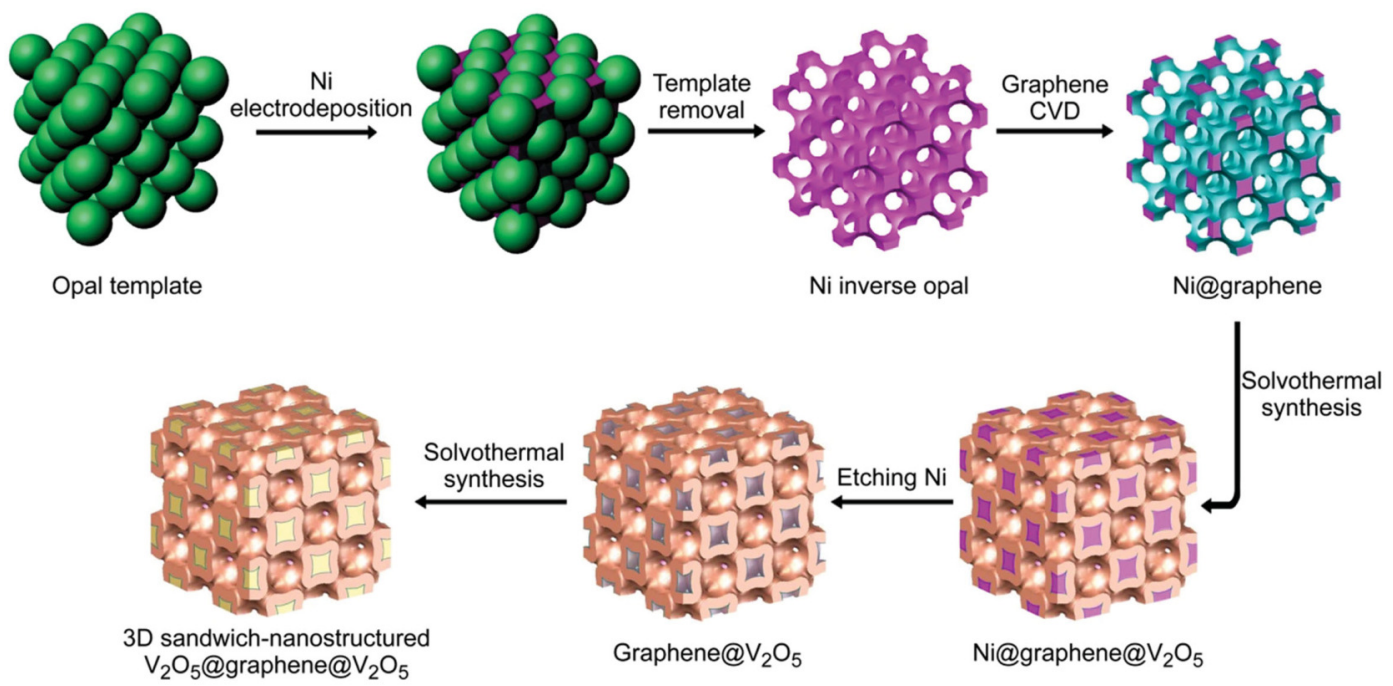

Figure 6. Schematic illustration for the fabrication of the 3D sandwich-structured $\mathrm{V}_{2} \mathrm{O}_{5} @$ graphene $@ \mathrm{~V}_{2} \mathrm{O}_{5}$ cathode. Reproduced with permission from [34]. Wiley, 2016.

\subsection{Sol-Gel Method}

Another widely used method for preparing 3D electrodes is sol-gel. For example, Park et al. reported a sol-gel method with polystyrene beads as templates to prepare $3 \mathrm{D} \mathrm{LiMn}_{2} \mathrm{O}_{4}$ thin films. A monolayer of polystyrene microspheres was first deposited on the surface of the substrates, which was the basis for manufacturing an open volume without overlaps in the perpendicular 
direction [35]. Subsequently, the prepared solvents containing precursor materials were dipped onto the substrates. After the calcination of deposited films, the polystyrene template was removed by the thermal decomposition. The precursor was converted to $\mathrm{LiMn}_{2} \mathrm{O}_{4}$. At last, a 3D spherical porous structure with an inverse-opal was formed. It was found that discharge capacity was associated with the annealing temperature, which has strong effects on the stable structure. Zhang et al. successfully encapsulated $\mathrm{Li}_{3} \mathrm{~V}_{2}\left(\mathrm{PO}_{4}\right)_{3}$ nanoparticles in amorphous carbon via a facile sol-gel method [36]. The presence of thin carbon layer and carbon network benefit $\mathrm{Li}^{+}$transport and electron conductivity. Applied as the cathode, this material exhibits a capacity of $85 \mathrm{mAh} \mathrm{g}^{-1}$ at a high rate of $30 \mathrm{C}$.

$\mathrm{Li}$ et al. reported a sol-gel method to construct the $3 \mathrm{D} \mathrm{LiAlO}_{2}-\mathrm{LiMnPO}_{4} / \mathrm{C}$ for a $\mathrm{Li}$-ion battery [37]. The $\mathrm{LiAiO}_{2}$ template was first constructed from an anodic aluminum oxide (AAO) template. Then, $\mathrm{LiMnPO}_{4} / \mathrm{C}$ filled in the pores of the prepared template, and finally formed a honeycomb-like structure. When used as the cathode of a Li-ion battery, this material shows a high capability of $105 \mathrm{mAh} \mathrm{g}^{-1}$ and $98.4 \%$ retention after 100 cycles at $10 \mathrm{C}$. The electrochemical performance has been improved due to the special core-shell architectures.

Ragupathi et al. reported a sol-gel method to synthesize spherical $\mathrm{LiCoBO}_{3}$ for use as the cathode material of a Li-ion battery [38]. The as-prepared material presents a capacity of $98 \mathrm{mAh} \mathrm{g}^{-1}$ at $10 \mathrm{C}$ after 52 cycles. The electrochemical performance of this material is superior to others derived from different methods, which may be ascribed to the formation of its spherical shape, which facilitates electron movement and Li-ion diffusion.

The sol-gel method is commonly low-cost and simple, which make it appropriate for preparing electrodes with a large yield. Particularly, their industrial manufacture always contains a sol-gel preparation.

\subsection{Solid-Based Approcah}

Despite the wet-chemical strategies introduced above, some solid-based approaches have also attracted intensive attention. Wang et al. successfully utilized a topochemical reaction route to synthesize porous $\mathrm{LiMn}_{2} \mathrm{O}_{4}$ spheres assembled by nanocrystalline, which took advantage of the porosity of $\mathrm{Mn}_{2} \mathrm{O}_{3}$ spheres obtained from the thermal decomposition of $\mathrm{MnCO}_{3}$ [39]. TEM and $\mathrm{N}_{2}$ adsorption-desorption measurements showed that the whole $\mathrm{LiMn}_{2} \mathrm{O}_{4}$ microspheres have an average size of about $45 \mathrm{~nm}$. It was observed that the interior of $\mathrm{LiMn}_{2} \mathrm{O}_{4}$ spheres, which showed a good performance in terms of capacity and cycling, were filled of abundant pores. The discharge capacity is $83 \mathrm{mAh} \mathrm{g}^{-1}$ at a rate of $20 \mathrm{C}$, which may be ascribed to the porous channels that are suitable for $\mathrm{Li}$ ion diffusion.

Huang et al. [40] used graphene and carbon nanotube conductive liquid (GNL) as a template to synthesize porous $\mathrm{Li}_{1.2} \mathrm{Mn}_{0.534} \mathrm{Ni}_{0.133} \mathrm{Co}_{0.133} \mathrm{O}_{2}$, as displayed in Figure 7. As for the GNL, CNTs are uniformly distributed on the layer of the graphene sheets. The manufacturing process of the composite is dependent on the preparation of $\mathrm{Li}_{1.2} \mathrm{Mn}_{0.534} \mathrm{Ni}_{0.133} \mathrm{Co}_{0.133} \mathrm{O}_{2}$ through a high-temperature calcination of spherical precursors of transition metal carbonate. For the porous GNL-LMNCO with the spherical particles, the secondary particles are composed of the primary particles with sizes of 150-180 $\mathrm{nm}$. The spheres of the secondary particles almost possess the same size of $2.0 \mathrm{~mm}$. A great number of pores can be obviously detected from the stacking of the primary particles. The porous Li-rich cathode delivers a discharge capacity of $235.5 \mathrm{mAh} \mathrm{g}^{-1}$, even after 100 cycles of charge/discharge, which suggests a high capacity retention of $86.2 \%$ compared to the initial capacity. 

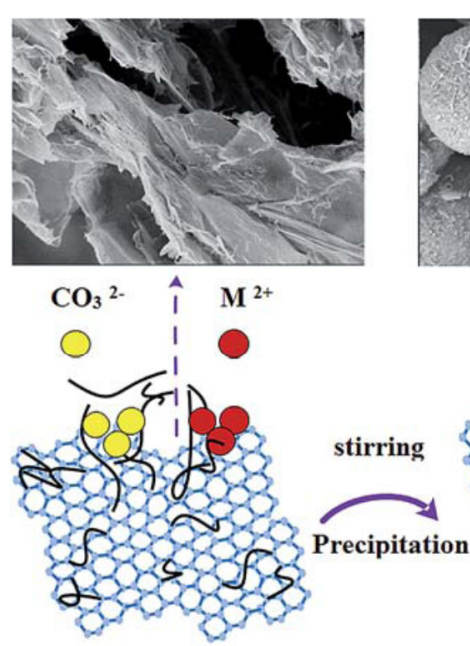

GNL template

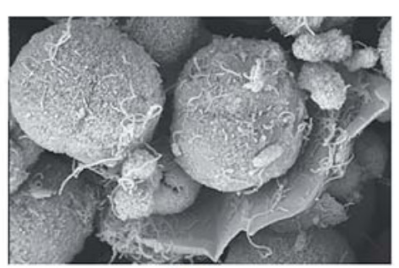

$\hat{\imath} \mathrm{MCO}_{3}$ 1

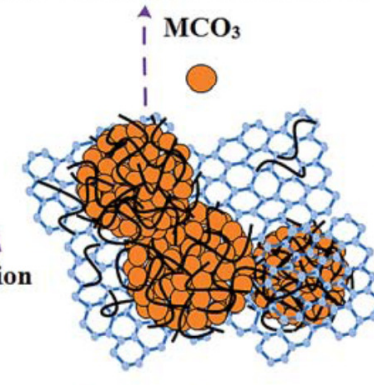

Carbonate precursor

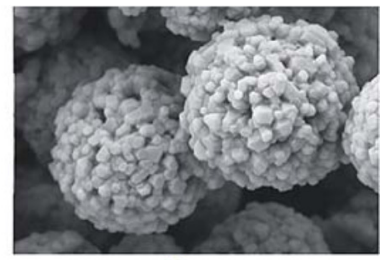

| LMNCO

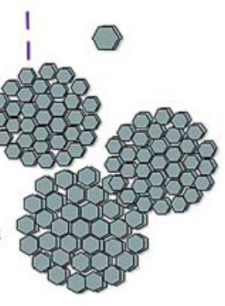

Porous structure

Figure 7. Formation mechanism of the porous graphene and carbon nanotube conductive liquid$\mathrm{Li}_{1.2} \mathrm{Mn}_{0.534} \mathrm{Ni}_{0.133} \mathrm{Co}_{0.133} \mathrm{O}_{2}$ cathode. Reproduced with permission from [40]. American Chemical Society, 2015.

In one study, de Biasi et al. synthesized a trigonal colquiriite-type crystal structure LiCaFeF6 via solid-state reaction approach [41]. This material's potential may be thanks to its safety and cycle life. When used as a cathode material, it exhibits a discharge capacity of $112 \mathrm{mAh} \mathrm{g}^{-1}$ and a maximum discharge current of $2.86 \mathrm{~V}$. This was assigned to the reduction of $\mathrm{Fe}^{3+}$ to $\mathrm{Fe}^{2+}$.

Baster et al. synthesized a series of $\mathrm{LiNi}_{0.6} \mathrm{Co}_{0.4-\mathrm{Z}} \mathrm{Ti}_{\mathrm{Z}} \mathrm{O}_{2}(\mathrm{z}=0.1,0.2,0.3)$ for the cathode materials of Li-ion batteries and compared their structural, transport, and electrochemical properties [42]. Of three materials, $\mathrm{LiNi}_{0.6} \mathrm{Co}_{0.3} \mathrm{Ti}_{0.1} \mathrm{O}_{2}$ exhibits a discharge capacity of $100 \mathrm{mAh} \mathrm{g}{ }^{-1}$ at $20 \mathrm{C}$.

\subsection{Other Methods}

Differing from the methods shown above, there are some other preparation approaches for making 3D cathodes for Li-ion batteries, including freeze-drying, chemical vapor deposition, vacuum filtration, and others. For instance, Doherty et al. synthesized beads of poly methyl methacrylate with different diameters as colloidal crystal templates to produce $\mathrm{LiFePO}_{4}$ with featured pores [43]. The use of colloidal crystal templates allowed an examination of the effects of pore size in terms of the electrochemical properties. The materials with the largest pores, around $100 \mathrm{~nm}$ diameter, exhibited the best discharge capacities of $160 \mathrm{mAh} \mathrm{g}^{-1}$ at $0.1 \mathrm{C}$ and $115 \mathrm{~mA} \mathrm{~h} \mathrm{~g}^{-1}$ at $5 \mathrm{C}$, respectively.

Tu et al. synthesized the 3D porous $\mathrm{LiFePO}_{4}$ materials modified with the uniformly dispersed nitrogen-doped carbon nanotubes (N-CNTs) by a freeze-drying method [44]. It included three steps: rapid freezing, vacuum freeze-drying, and a heating treatment. The synthesized porous $\mathrm{LiFePO}_{4} / \mathrm{NCNTs}$ composite demonstrates a specific capacity of $159 \mathrm{mAh} \mathrm{g}^{-1}$ at a rate of $0.1 \mathrm{C}$, a rate performance with a capacity of $72 \mathrm{mAh} \mathrm{g}^{-1}$ at a high rate of $10 \mathrm{C}$, and a high capacity retention of $96.7 \%$ after 500 charge/discharge cycles.

Zhao et al. synthesized an orthorhombic $\mathrm{LiMnO}_{2}$ nanorod by in-situ carbothermal reduction [45]. This approach included two steps: preparation of $\mathrm{MnO}_{2}$ nanorod and carbothermal reduction to obtain $\mathrm{LiMnO}_{2}$. When used as a cathode in a Li-ion battery, this material exhibits outstanding electrochemical performance of $165.3 \mathrm{mAh} \mathrm{g}^{-1}$ at $0.1 \mathrm{C}$ and $92.6 \%$ retention after 40 cycles. As for manganates, Duan et al. synthesized the $\mathrm{LiMn}_{2} \mathrm{O}_{4}$ hollow nanofibers with a porous structure by modified electrospinning techniques on the fluorine-doped tin oxide glass [46]. The cathode made of these hollow materials delivered a specific capacity of $125.9 \mathrm{mAh} \mathrm{g}^{-1}$ and a cycling performance of $105.2 \mathrm{mAh} \mathrm{g}^{-1}$ after 400 cycles at $0.1 \mathrm{C}$, which exhibited a good battery performance. 
A 3D mace-like $\mathrm{Li}_{3} \mathrm{~V}_{2}\left(\mathrm{PO}_{4}\right)_{3} / \mathrm{C}$ nanowire and nanofiber membrane was prepared by using nanoparticles as a catalyst [47]. The fabrication process combines a modified electrospinning method with a hot-press treatment. The surface of the fibers is covered with nanowires that grow in situ, forming a mace-like morphology. Based on the mechanical property of the composite, the long-rangenetworking membrane is directly available for self-standing cathodes. The obtained cathode exhibits a good rate performance and cyclic stability in the voltage range of 3.0-4.8 V. Discharge capacities of $115.3 \mathrm{mAh} \mathrm{g}^{-1}$ and $108.6 \mathrm{mAh} \mathrm{g}^{-1}$ at $5 \mathrm{C}$ and $10 \mathrm{C}$ are achieved, respectively. As for the capacity retention, it is $81.4 \%$ after 500 cycles, and $78.8 \%$ after 1000 cycles, showing quite good stability. $\mathrm{Li}$ et al. successfully synthesized a $\mathrm{Li}_{3} \mathrm{~V}_{2}\left(\mathrm{PO}_{4}\right)_{3} / \mathrm{C}$ composite with $3 \mathrm{D}$ foam-core structure via a facile immersion method [48]. The uniform $\mathrm{Li}_{3} \mathrm{~V}_{2}\left(\mathrm{PO}_{4}\right)_{3} / \mathrm{C}$ bubbles were observed. $\mathrm{Li}_{3} \mathrm{~V}_{2}\left(\mathrm{PO}_{4}\right)_{3}$ nanoparticles were coated uniformly by an amorphous carbon layer. The cathode exhibits a good rate performance with a specific capacity of $100 \mathrm{mAh} \mathrm{g}^{-1}$ at $15 \mathrm{C}$ in the potential range of 3.0-4.3 V, which is attributed to the $3 \mathrm{D}$ porous frog egg-like structure. Zhu et al. reported the synthesis of 3D microporous graphene- $\mathrm{Li}_{2} \mathrm{FeSiO}_{4} / \mathrm{C}$ nanocomposites [49]. As displayed in Figure 8, the 3D porous graphene framework was obtained through a templated-assembly method. During the preparation process, the surface grafted and positively charged $\mathrm{SiO}_{2}$ spheres were assembled with negatively charged graphene oxide (GO) sheets by electrostatic interactions. The $\mathrm{SiO}_{2}$ spheres were then removed, forming a 3D porous graphene framework. Finally, a $\mathrm{Li}_{2} \mathrm{FeSiO}_{4}$ precursor gel was coated and annealed to get the 3D G/ $/ \mathrm{Li}_{2} \mathrm{FeSiO}_{4} / \mathrm{C}$ composite. These composite have the advantage of the porosity of a 3D structure and the conductivity of graphene, with the discharge capacities reaching $255 \mathrm{mAh} \mathrm{g}^{-1}$ at $1 \mathrm{C}^{\text {. }}$

(a)

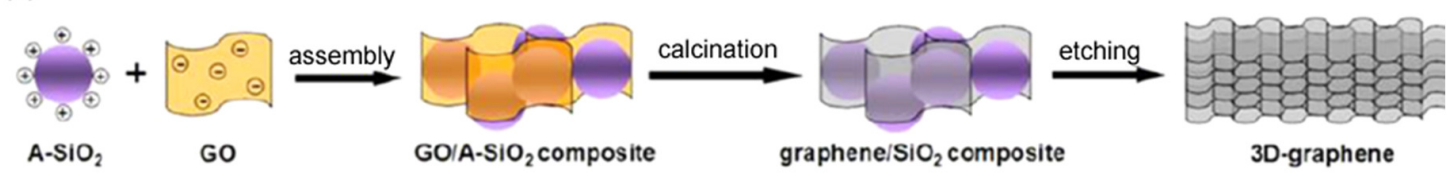

(b)

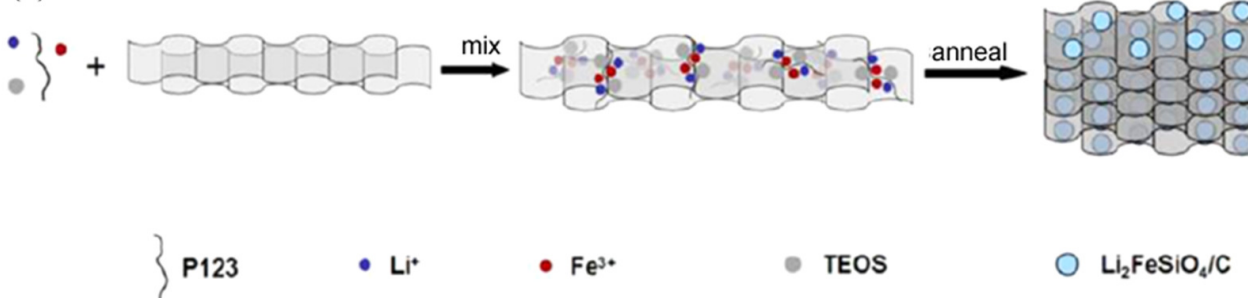

Figure 8. Illustrations of the synthesis procedures of (a) the 3D porous graphene and (b) the graphene/ $\mathrm{Li}_{2} \mathrm{FeSiO}_{4} / \mathrm{C}$ composite. Reproduced with permission from [49]. American Chemical Society, 2014.

In addition, a flexible, free standing, and light-weight $\mathrm{LiMnTiO}_{4} / \mathrm{MWCNT}$ was synthesized by vacuum filtration method [50]. The prepared material possesses a 3D structure, where CNT networks are well wrapped in $\mathrm{LiMnTiO}_{4}$ particles. For superior performance aspects, such as flexibility, low weight, and high mechanical property, this material was used as a free-standing cathode and delivers a capacity of $161 \mathrm{mAh} \mathrm{g}^{-1}$ and $86.4 \%$ retention after 50 cycles at $0.5 \mathrm{C}$. This may be due to the promotion of $\mathrm{Li}^{+}$and electron transformation through the porous, MWCNTs. More details about the comparison with some 3D Li-ion battery cathodes are listed in Table 1. 
Table 1. Comparison on the performance of three-dimensional Li-ion battery cathodes.

\begin{tabular}{|c|c|c|c|c|c|}
\hline Cathode Materials & Preparation Method & Cycling Rate & Cycle Number & Capacity $\left(\mathrm{mAh} \mathrm{g}^{-1}\right)$ & References \\
\hline $\mathrm{Li}_{3} \mathrm{VP}_{3} \mathrm{ON}$ & $\begin{array}{l}\text { Solid-solid ion-exchange } \\
\text { method }\end{array}$ & $20 \mathrm{C}$ & 50 & 70 & [51] \\
\hline $\mathrm{Li}_{3} \mathrm{~V}_{2}\left(\mathrm{PO}_{4}\right)_{3} / \mathrm{C}$ & Sol-gel method & $30 \mathrm{C}$ & 35 & 85 & [36] \\
\hline $\mathrm{LiAlO}_{2}-\mathrm{LiMnPO}_{4} / \mathrm{C}$ & Sol-gel method & $10 \mathrm{C}$ & 100 & 105 & [37] \\
\hline $\begin{array}{c}(1-\mathrm{x}) \mathrm{LiNi}_{0.5} \mathrm{Mnn}_{1.5} \mathrm{O}_{4^{-}} \\
\mathrm{xLi}_{2} \mathrm{SiO}_{3}\end{array}$ & Sol-gel method & $2 \mathrm{C}$ & 50 & 150.3 & [52] \\
\hline $\mathrm{G} / \mathrm{LiFePO}_{4} / \mathrm{G}$ & Hydrothermal method & $10 \mathrm{C}$ & 100 & 124 & [53] \\
\hline $\mathrm{Li}_{3} \mathrm{Mo}_{4} \mathrm{P}_{5} \mathrm{O}_{24}$ & - & $50 \mathrm{C}$ & 20 & 110 & [54] \\
\hline $\mathrm{Li}_{2} \mathrm{FeSiO}_{4} / \mathrm{C}$ & - & $10 \mathrm{C}$ & 420 & 239 & [55] \\
\hline $\mathrm{LiCaFeF}_{6}$ & Solid-state reaction & $20 \mathrm{C}$ & 20 & 112 & [41] \\
\hline CNT@Li $\mathrm{MnSiO}_{4} @ \mathrm{C}$ & - & $0.2 \mathrm{C}$ & 50 & 227 & [56] \\
\hline $\mathrm{Li}_{3} \mathrm{FeF}_{6}$ & Sol-gel Mechanical stirring & $50 \mathrm{~mA} \mathrm{~g}^{-1}$ & 100 & 174 & [57] \\
\hline $\mathrm{LiFePO}_{4} @ \mathrm{C}$ & Hydrothermal & $10 \mathrm{C}$ & 500 & 117 & [58] \\
\hline $\mathrm{LiMnO}_{2}$ & $\begin{array}{l}\text { In-situ carbothermal } \\
\text { reduction method }\end{array}$ & $0.1 \mathrm{C}$ & 40 & 165.3 & [48] \\
\hline $\mathrm{LiCoPO}_{4}$ & $\begin{array}{l}\text { Microwave-assisted } \\
\text { solvothermal }\end{array}$ & $0.1 \mathrm{C}$ & 20 & 141 & [59] \\
\hline $\mathrm{Li}_{2} \mathrm{MnO}_{3}$ & Sol-gel method & $0.1 \mathrm{C}$ & 100 & 225 & [60] \\
\hline $\mathrm{Li}_{2} \mathrm{FeSiO}_{4}$ & Polyol method & $20 \mathrm{C}$ & 50 & 270 & [61] \\
\hline $\mathrm{LiVPO}_{4} \mathrm{~F} / \mathrm{C}$ & Sol-gel method & $10 \mathrm{C}$ & 20 & 121.1 & [62] \\
\hline $\mathrm{LiMn}_{0.8} \mathrm{Fe}_{0.2} \mathrm{PO}_{4}$ & Solvothermal method & $3 \mathrm{C}$ & 35 & 171 & [63] \\
\hline LiMnBO $3 @ \mathrm{C}$ & Sol-gel method & $0.05 \mathrm{C}$ & 50 & 159.7 & [64] \\
\hline $\mathrm{LiMn}_{2} \mathrm{O}_{4}$ & Hydrothermal method & $0.2 \mathrm{C}$ & 1000 & 143.4 & [65] \\
\hline $\mathrm{LiMnTiO}_{4}$ & Vacuum filtration method & $0.5 \mathrm{C}$ & 50 & 161 & [50] \\
\hline Nano- $\mathrm{SiO}_{2} @ \mathrm{Li}_{2} \mathrm{CoPO}_{4} \mathrm{~F}$ & Hydrothermal method & $2 \mathrm{C}$ & 60 & 79.4 & [66] \\
\hline $\mathrm{LiVP}_{2} \mathrm{O}_{7} / \mathrm{C}$ & Sol-gel method & $0.05 \mathrm{C}$ & 50 & 102.3 & [67] \\
\hline $\mathrm{LiFeBO}_{3} / \mathrm{C}$ & Spray-drying & $0.05 \mathrm{C}$ & 105 & 201.5 & [68] \\
\hline $\mathrm{LiV}_{3} \mathrm{O}_{8}$ & $\begin{array}{l}\text { High-temperature } \\
\text { calcination }\end{array}$ & $60 \mathrm{~mA} \mathrm{~g}^{-1}$ & 100 & 212.8 & [69] \\
\hline $\mathrm{Li}_{2} \mathrm{CoSiO}_{4} / \mathrm{C}$ & Hydrothermal method & $36 \mathrm{~mA} \mathrm{~g}^{-1}$ & 100 & 144 & [70] \\
\hline $\mathrm{LiMo}_{4} \mathrm{O}_{6}$ & Ion-exchange method & $0.05 \mathrm{C}$ & 50 & 36.3 & [71] \\
\hline $\mathrm{LiNi}_{0.5} \mathrm{Co}_{0.2} \mathrm{Mn}_{0.3} \mathrm{O}_{2}$ & - & $0.1 \mathrm{C}$ & 100 & 164.6 & [72] \\
\hline $\mathrm{LiCoBO}_{3}$ & Sol-gel method & $10 \mathrm{C}$ & 52 & 98 & [41] \\
\hline $\mathrm{LiNi}_{0.08} \mathrm{Mn}_{1.92} \mathrm{O}_{4}$ & $\begin{array}{l}\text { Solution combustion } \\
\text { method }\end{array}$ & $1 \mathrm{C}$ & 1000 & 95.7 & [73] \\
\hline $\mathrm{LiNi}_{0.6} \mathrm{Co}_{0.4-\mathrm{z}} \mathrm{Ti}_{\mathrm{z}} \mathrm{O}_{2}$ & Solid-state method & 20 & 50 & 100 & [42] \\
\hline $\mathrm{LiFe}_{0.4} \mathrm{Mn}_{0.4} \mathrm{Co}_{0.2} \mathrm{PO}_{4} / \mathrm{C}$ & $\begin{array}{l}\text { coprecipitation-and-milling } \\
\text { method }\end{array}$ & $1 \mathrm{C}$ & 100 & 104.7 & [74] \\
\hline $\mathrm{Li}_{2} \mathrm{Ru}_{0.8} \mathrm{Ti}_{0.2} \mathrm{O}_{3}$ & & $100 \mathrm{~mA} \mathrm{~g}^{-1}$ & 90 & 196.1 & [75] \\
\hline $\mathrm{Li}_{4} \mathrm{Ti}_{5} \mathrm{O}_{12}-\mathrm{LiNi}_{0.5} \mathrm{Mn}_{1.5} \mathrm{O}_{4}$ & Solvothermal method & $0.5 \mathrm{C}$ & 100 & 122.6 & [76] \\
\hline
\end{tabular}

\section{Methods for Constructing 3D Porous Li-S Battery Cathodes and Their Comparison}

\subsection{D Porous S Cathodes for Li-S Batteries}

There are several reasons that the elemental sulfur itself cannot be fabricated as the cathode in Li-S batteries. One is that the sulfur is insulative and does not have a firm crystal to form a solid structure. In this case, after sulfur reacts with lithium ions, the resultant $\mathrm{Li}_{2} \mathrm{~S}$ cannot be fixed in situ. The alternative method is to combine sulfur with other conductive materials. A frame strategy is promising and viable for solving the issues of elemental sulfur by coating sulfur onto a frame that has good conductivity, a large surface, and a porous structure [77-79]. Until now, carbon materials, conductive polymers, and metal or metal oxides have been studied for sulfur-based cathode materials. 
The energy stored in Li-S batteries is closely related to the mass of the sulfur. As such, 3D porous structures are desired to increase the mass loading.

Various kinds of carbon matrices, including carbon nanotubes, graphene, carbon nanofibers, carbon spheres, and mesoporous carbon, have been chosen to act as a frame for Li-S batteries. In addition, the fabrication of conceptually new structures is also attractive. For example, Lu et al. reported an approach to assemble a sulfur-graphene sponge with sulfur uniformly distributed into the pores of a graphene sponge [80]. The graphene sponge framework can not only improve the electronic conductivity but also accommodate the volume change in the charge and discharge process. The electrochemical measurement showed a high areal specific capacity of $4.53 \mathrm{mAh} \mathrm{cm}{ }^{-2}$ after 300 cycles and a slow decay rate of $0.08 \%$ per cycle after 300 cycles at $0.1 \mathrm{C}$. To some extent, the interlaced graphene layer can absorb the polysulfides intermediate product. More performance comparison about 3D S cathodes are listed in Table 2.

Li et al. reported a novel 3D hierarchical polypyrrole loading sulfur [81]. Firstly, silica colloid crystal was used as a template to synthesize 3D polypyrrole, which possesses a large specific area. Subsequently, sulfur was loaded on the surface of polypyrrole via a solution-diffusion route followed by low-temperature treatment. When used as cathode for Li-S batteries, this material shows a high specific capacity of $751 \mathrm{mAh} \mathrm{g}^{-1}$ after 100 cycles at $0.1 \mathrm{C}$.

A wood-inspired multi-channel tubular graphene architecture prepared by chemical vapor deposition was also studied [82]. This unique structure provides a large interior space that accommodates sulfur and fixes the generated polysulfide. Meanwhile, the 3D multi-channel network also promotes mass transport and ion diffusion. The benefit from these properties is that the MCTG/S cathode for Li-S batteries delivers a discharge capacity of $1390 \mathrm{mAh} \mathrm{g}^{-1}$ at $0.1 \mathrm{C}$.

Two composites of ZnO@S/CNT and $\mathrm{Ni}(\mathrm{OH})_{2} @ S / C N T$ were reported and applied in Li-S batteries [83]. ZnO@S/CNT illustrates higher initial capacity of $1663 \mathrm{mAh} \mathrm{g}^{-1}$ and $56.6 \%$ retention after 70 cycles. It can be attributed to the strong interaction between $\mathrm{ZnO}$ and $\mathrm{S}_{\mathrm{x}}^{2-}$ based on density functional theory (DFT) calculation.

Moreover, $\mathrm{Li}$ et al. synthesized $\mathrm{Ni}_{3} \mathrm{~S}_{2}$ and coated it onto the surface of $\mathrm{Ni}$ foam by the hydrothermal method, followed by physically coating elemental $\mathrm{S}$, and finally obtained $3 \mathrm{D} \mathrm{Ni} / \mathrm{Ni}_{3} \mathrm{~S}_{2} / \mathrm{S}$ [84]. As displayed in Figures 9 and 10, the reaction between Ni metal and sulfur generates $\mathrm{Ni}_{3} \mathrm{~S}_{2}$ in situ on the surface of the Ni foam. Within the hybrid, the inner Ni metal network could serve as an electron transport pathway to facilitate the electrochemical reactions. In addition, the sufficient pore spaces enable a high sulfur loading and endure the volume change caused by the sulfur. When the loading amount is $4 \mathrm{mg} \mathrm{cm}^{-2}$, this material delivers a discharge capacity of $441 \mathrm{mAh} \mathrm{g}^{-1}$ after 100 cycles.

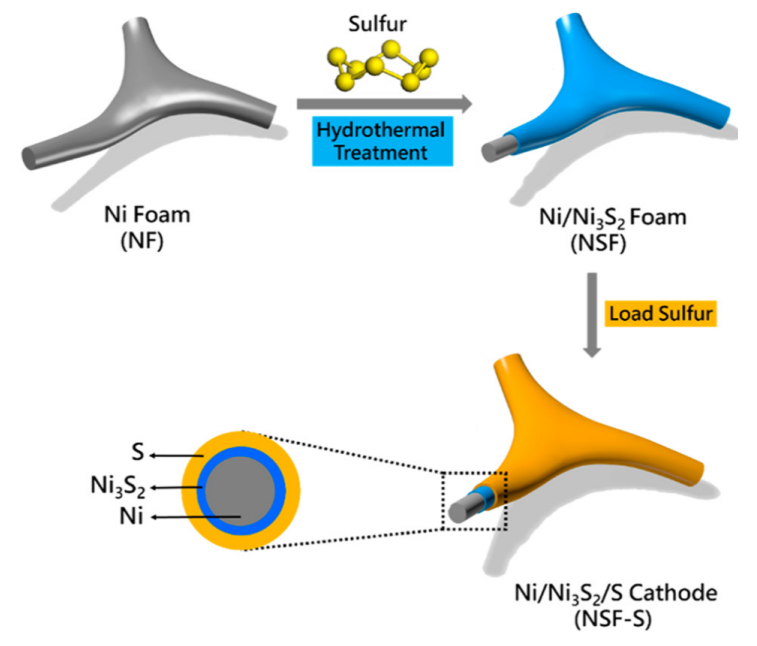

Figure 9. Schematic illustration of the $\mathrm{Ni} / \mathrm{Ni}_{3} \mathrm{~S}_{2} / \mathrm{S}$ hybrid cathode. Reproduced with permission from [84]. American Chemical Society, 2017. 


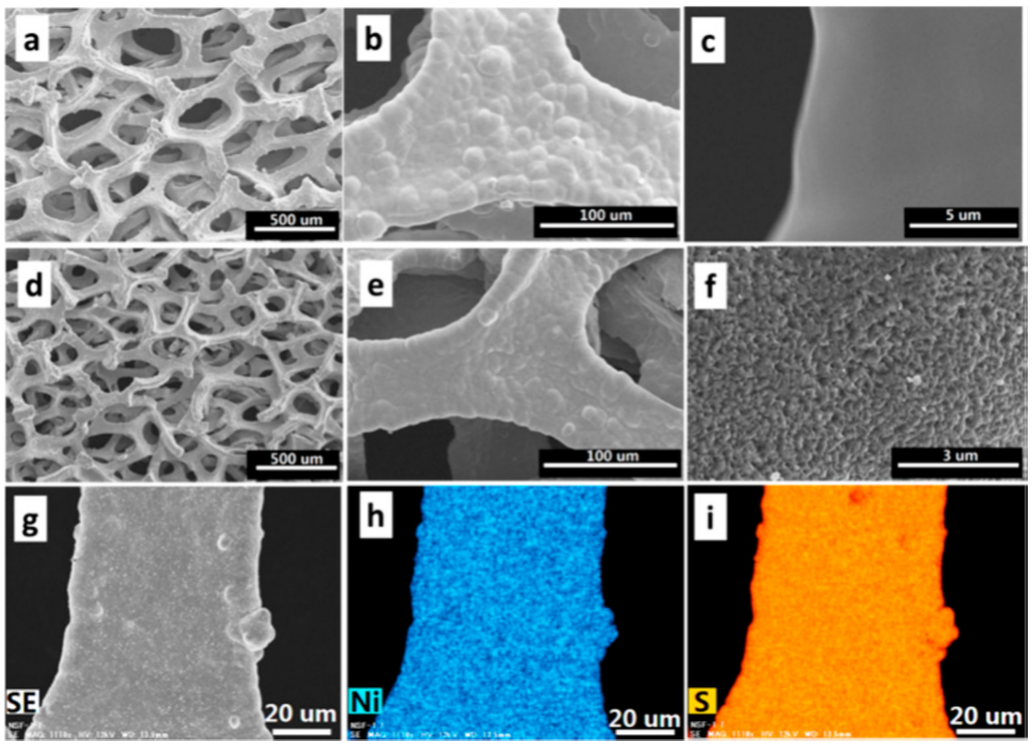

Figure 10. SEM images of $(\mathbf{a}-\mathbf{c})$ nickel foam and $(\mathbf{d}-\mathbf{g})$ nickel-sulfur foam at different magnifications. (h) Energy dispersive X-ray spectroscopy elemental mappings of nickel and (i) sulfur over image (g). Reproduced with permission from [84]. American Chemical Society, 2017.

The in situ construction method was also used for preparing oxide-based composites. For example, Song et al. reported $\mathrm{VO}_{2}-\mathrm{VN}$ as an excellent sulfur host for Li-S batteries [85]. The $\mathrm{S} @ \mathrm{VO}_{2}-\mathrm{VN}$ cathode displayed a remarkable rate capacity of $935 \mathrm{mAh} \mathrm{g}^{-1}$ and $56.1 \%$ retention after 800 cycles at $2 \mathrm{C}$. As illustrated in Figure 11, the good performance ascribed to the improved interfacial contact between $\mathrm{VO}_{2}$ and $\mathrm{VN}$ built-up by the in situ construction route guarantees fast diffusion of LiPSs from $\mathrm{VO}_{2}$ to $\mathrm{VN}$, resulting in an improved conversion and accelerated redox kinetics towards $\mathrm{Li}_{2} \mathrm{~S}$ precipitation.

a

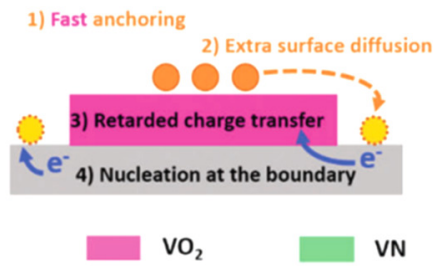

b

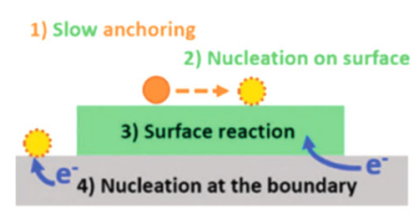

Carbon materials
C

5) Increased interface 1) Fast anchoring diffusion 2) Extra surface diffusion 6) Increasec nucleation $\mathrm{e}^{-13)}$ Improved charge transfer ( $\mathrm{e}^{-}$) Nucleation at the boundary $\mathrm{e}$

Polysulfides

Lithium sulfides

Figure 11. Illustration of LiPS anchoring-diffusion-conversion processes on $\mathrm{VO}_{2}, \mathrm{VN}$, and $\mathrm{VO}_{2}-\mathrm{VN}$ binary host surfaces. Reproduced with permission from [85]. The Royal Society of Chemistry, 2018.

Several oxide-based cathodes were reported to possess the adsorptive capability towards polysulfides, including $\mathrm{Li}_{2} \mathrm{~S}_{2}, \mathrm{Li}_{2} \mathrm{~S}_{4}$, and $\mathrm{Li}_{2} \mathrm{~S}_{6}$. It is necessary to reduce the shuttle effect of a $\mathrm{Li}-\mathrm{S}$ battery, leading to improved stability. In contrast, the sulfur-based cathodes commonly suffer from loss of active materials because of the dissolving and transferring of polysulfides. The relatively high loading is more attractive for sulfur-based cathodes, as the oxide hosts are usually of large weight and volume compared to the active component sulfur within the electrodes. As for the preparation of Li-S battery cathode, many techniques used for making Li-ion battery cathodes are also applicable. Some methods are summarized in Table 2. However, what should be noted is that the low melting point of sulfur makes the high-temperature treatment unsuitable. 
Table 2. Comparison on the performance of 3D cathodes in Li-S batteries.

\begin{tabular}{|c|c|c|c|c|c|c|}
\hline Cathode Materials & Preparation Method & $\begin{array}{l}\text { Cycling } \\
\text { Rate }\end{array}$ & $\begin{array}{l}\text { Cycle } \\
\text { Number }\end{array}$ & $\begin{array}{l}\text { Capacity } \\
\left(\mathrm{mAh}^{-1}\right)\end{array}$ & $\begin{array}{c}\text { S/E } \\
\text { (Weight Ratio) }\end{array}$ & References \\
\hline 3D sulfur-doped graphene & $\begin{array}{l}\text { One-pot wet chemical } \\
\text { method }\end{array}$ & $0.5 \mathrm{C}$ & 350 & 785 & $80 \%$ & [86] \\
\hline $\begin{array}{l}\text { Hierarchically porous nitrogen-doped } \\
\text { carbon }\end{array}$ & - & $0.1 \mathrm{C}$ & 300 & 1355 & $69 \%$ & [87] \\
\hline$\alpha-\mathrm{MoO}_{3}$ & - & $0.5 \mathrm{C}$ & 400 & 912.8 & $68 \%$ & [88] \\
\hline Porous polypyrrole loading sulfur & $\begin{array}{l}\text { Chemical polymerization } \\
\text { method }\end{array}$ & $0.1 \mathrm{C}$ & 100 & 751 & $59 \%$ & [81] \\
\hline $\begin{array}{l}\text { Wood inspired multi-channel tubular } \\
\text { graphene }\end{array}$ & $\begin{array}{l}\text { Template-directed } \\
\text { chemical vapor } \\
\text { deposition }\end{array}$ & $0.1 \mathrm{C}$ & 500 & 1390 & $70 \%$ & {$[82]$} \\
\hline 3D N-doped graphene foam & $\begin{array}{l}\text { Annealing method in } \\
\text { chemical vapor } \\
\text { deposition }\end{array}$ & $0.2 \mathrm{C}$ & 200 & 819 & $\begin{array}{c}2.05 \mathrm{mg} \\
\mathrm{cm}^{-2}\end{array}$ & [89] \\
\hline $\mathrm{S} / \mathrm{CeO}_{2} / \mathrm{RGO}$ (reduced graphene oxide) & Hydrothermal method & $0.1 \mathrm{C}$ & 20 & 792 & $64 \%$ & [90] \\
\hline $\mathrm{Li}_{2} \mathrm{~S} /$ graphene & Infiltration method & $0.1 \mathrm{C}$ & 300 & 894.7 & & [91] \\
\hline CNTs/MOFs-C/ $/ \mathrm{Al}_{2}(\mathrm{OH})_{2.76} \mathrm{~F}_{3.24} / \mathrm{S}$ & - & $500 \mathrm{~mA} \mathrm{~g}^{-1}$ & 300 & 889 & $72 \%$ & [92] \\
\hline Polypyrrole@sulfur@polypyrrole & $\begin{array}{l}\text { Chemical precipitation } \\
\text { method }\end{array}$ & $50 \mathrm{~mA} \mathrm{~g}^{-1}$ & 50 & 554 & $66 \%$ & [93] \\
\hline Porous $\mathrm{C}_{3} \mathrm{~N}_{4}$ nanosheets@RGO & - & $0.5 \mathrm{C}$ & 800 & 680 & $68 \%$ & [94] \\
\hline Titanium-dioxide-grafted carbon paper & - & $0.5 \mathrm{C}$ & 200 & 850 & $40 \%$ & [95] \\
\hline $\mathrm{Nd}_{2} \mathrm{O}_{3}$ nanoparticles doped carbon & Acid catalyzing method & $0.2 \mathrm{C}$ & 100 & 1082 & $56 \%$ & [96] \\
\hline $\mathrm{CeF}_{3}$-doped porous carbon nanofibers & $\begin{array}{l}\text { Electroblown spinning } \\
\text { technique and } \\
\text { carbonization process }\end{array}$ & $0.5 \mathrm{C}$ & 500 & 901.2 & $75 \%$ & [97] \\
\hline 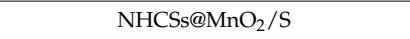 & - & $0.5 \mathrm{C}$ & 1000 & 1249 & $70 \%$ & [98] \\
\hline ZnO@S/CNT & Ball-milling method & $160 \mathrm{~mA} \mathrm{~g}^{-1}$ & 70 & 942 & $45 \%$ & [83] \\
\hline TiN@CNT-S & - & $0.05 \mathrm{C}$ & 80 & 1269 & $5.4 \mathrm{mg} \mathrm{cm}^{-2}$ & [99] \\
\hline $\mathrm{NiCO}_{2} \mathrm{O}_{4}$ & Solvothermal method & $0.2 \mathrm{C}$ & 200 & 1274 & $27 \%$ & [100] \\
\hline S/AHCNS-SnS 2 & - & $0.2 \mathrm{C}$ & 200 & 924 & $64 \%$ & [101] \\
\hline $\mathrm{Ni} / \mathrm{Ni}_{3} \mathrm{~S}_{2} / \mathrm{S}$ & Hydrothermal method & $4 \mathrm{~mA} \mathrm{~cm}^{-1}$ & 150 & 441 & $71 \%$ & {$[84]$} \\
\hline $\mathrm{TiB}_{2} / \mathrm{S}$ & Melting-diffusion method & $1 \mathrm{C}$ & 100 & 837 & $70 \%$ & [102] \\
\hline $\mathrm{Mn}_{3} \mathrm{O}_{4} @ \mathrm{CNF} / \mathrm{S}$ & & $0.1 \mathrm{C}$ & 100 & 993 & $50 \%$ & [103] \\
\hline $\mathrm{Li}_{2} \mathrm{~S} /$ carbon & Icy water bathing method & $0.2 \mathrm{C}$ & 150 & 595 & - & [104] \\
\hline $\begin{array}{c}\mathrm{Ti}_{4} \mathrm{O}_{7} \text { nanoparticle-embedded porous } \\
\text { carbon }\end{array}$ & - & $0.2 \mathrm{C}$ & 1000 & 1445 & $77 \%$ & [105] \\
\hline $\mathrm{S} / \mathrm{Ti}_{3} \mathrm{C}_{2} \mathrm{~T}_{\mathrm{x}}$ & Melt-diffusion method & $5 \mathrm{C}$ & 1500 & 608 & $80 \%$ & [106] \\
\hline $\mathrm{VO}_{2}$-VN & Hydrothermal & $1 \mathrm{C}$ & 800 & 1105 & $62 \%$ & [85] \\
\hline $\mathrm{Li}_{2} \mathrm{~S} @ \mathrm{C}-\mathrm{Co}-\mathrm{N}$ & $\begin{array}{c}\text { Liquid } \\
\text { infiltration-evaporation } \\
\text { method }\end{array}$ & $1 \mathrm{C}$ & 300 & 950.6 & - & [107] \\
\hline 3D CNTs/Graphene-S- $\mathrm{Al}_{3} \mathrm{Ni}_{2}$ & - & $1 \mathrm{C}$ & 800 & 496 & $65 \%$ & [108] \\
\hline Bamboo-like $\mathrm{Co}_{3} \mathrm{O}_{4}$ & Hydrothermal method & $1 \mathrm{C}$ & 300 & 796 & $72.6 \%$ & [109] \\
\hline $\mathrm{MnO}_{2}-\mathrm{Ti}_{3} \mathrm{C}_{2}$ & $\begin{array}{l}\text { Electrostatic self-assembly } \\
\text { approach }\end{array}$ & $2 \mathrm{C}$ & 500 & 844.5 & $70 \%$ & [110] \\
\hline $\mathrm{S} @ \mathrm{TiO}_{2} / \mathrm{PPy}$ & - & $0.2 \mathrm{C}$ & 50 & 745.6 & $72.4 \%$ & [111] \\
\hline $\mathrm{TiC}-\mathrm{TiO}_{2} / \mathrm{S}$ & - & $0.5 \mathrm{C}$ & 500 & 714 & $1.1 \mathrm{mg} \mathrm{cm}^{-2}$ & [112] \\
\hline
\end{tabular}

\subsection{Brief Comparison between Li-Ion and Li-S Batteries}

As for the Li-ion batteries, they are advantageous as they show good safety, high working voltage, good specific capacity at low cycling rate, long cyclic performance, and low self-discharge. In parallel, for the Li-S batteries, capacities are commonly from 700 to $1500 \mathrm{mAh} \mathrm{g}^{-1}$, which are competitive with some other batteries. Nevertheless, there are some challenges for Li-S batteries, such as the dissolution of polysulfide in electrolyte, poor conductivity of sulfur, and the damage to the active materials caused from volume change. For example, the conductivity of $S$ means it needs more conductive carbon and polymer binder in the cathode, which decreases the mass content of active materials within the electrode. Therefore, improving the capacity of the Li-ion battery and increasing the loading of sulfur in the Li-S battery are necessary to achieve a good energy density in practice. 


\section{Summary}

Some important investigations on the 3D porous-structured electrodes for both Li-ion and Li-S batteries have been summarized. Compared to conventional thick-film electrodes, 3D porous electrodes enable fast electron and $\mathrm{Li}$ ion transfer, as well as a robust mechanical strength, and sufficient space for volume change accommodation during charge/discharge. However, 3D porous electrodes usually consume more electrolytes, which should be addressed in future studies. Potentially, constructing light-weight 3D frames and optimizing the porous structure could be promising. For such design and optimization, some artificial intelligence (AI) methods, such as genetic programming and automated neural network, are available [113]. They are able to establish models for optimizing battery pack enclosures for electric vehicles, and analyzing the capacities for electrodes $[114,115]$, which is necessary for achieving an optimal 3D-structured electrode [116]. As demonstrative examples, $\mathrm{LiCoO}_{2}, \mathrm{LiMn}_{2} \mathrm{O}_{4}$, $\mathrm{LiFePO}_{4}, \mathrm{~V}_{2} \mathrm{O}_{5}, \mathrm{LiNi}_{1-\mathrm{x}-\mathrm{y}} \mathrm{Co}_{\mathrm{x}} \mathrm{Mn}_{\mathrm{y}} \mathrm{O}_{2}$ in pristine and modified forms with a $3 \mathrm{D}$ porous structure for $\mathrm{Li}$-ion batteries have been introduced, while $\mathrm{S}$ loaded on 3D nanoframes for Li-S batteries are discussed as well. The preparation approaches, including template-directed chemical vapor deposition, hydrothermal synthesis, atomic layer deposition, and the related electrochemical properties, are focused on. In view of the limited length of the mini review, some of the methods have not been discussed in depth. There are still some electrode materials out of the range of this review. However, we hope the review presented here could potentially be significant for researchers and engineers who are working in related fields. In addition, it is believed that 3D porous-structured materials for next generation cathodes are promising, which would be of benefit for developing high-performance advanced secondary batteries.

Author Contributions: Investigation, J.L. (Jinyun Liu) and J.L. (Jinjin Li); resources, J.W.L., S.D., B.S., and S.G.Z.; writing—original draft preparation, J.L. (Jinyun Liu), J.W.L., S.D., and J.L. (Jinjin Li); writing—review and editing J.L. (Jinyun Liu), J.W.L., S.D., B.S., S.G.Z., and J.L. (Jinjin Li); supervision, J.L. (Jinyun Liu) and J.L. (Jinjin Li); project administration, J.L. (Jinyun Liu), B.S., S.G.Z., and J.L. (Jinjin Li); funding acquisition, J.L. (Jinyun Liu), B.S., S.G.Z., and J.L. (Jinjin Li).

Funding: This research was funded by National Natural Science Foundation of China (grant numbers: 51672176, 661573334, and 61873003), Science and Technology Major Project of Anhui Province (grant numbers: 18030901093 and 16030801118), Major Project of the Anhui Provincial Department of Education (grant numbers: KJ2018ZD034, KJ2016SD14, and KJ2017ZD40), Creative Science Foundation of AHNU (grant number: 2018XJJ108), and Intergovernmental International Scientific and Technological Cooperation of Shanghai (grant number: 17520710200). The APC was funded by Science and Technology Major Project of Anhui Province (grant number: 18030901093).

Conflicts of Interest: The authors declare no conflict of interest.

\section{References}

1. Blomgren, G.E. The development and future of lithium ion batteries. J. Electrochem. Soc. 2017, 164, A5019-A5025. [CrossRef]

2. Seh, Z.; Sun, Y.; Zhang, Q.; Cui, Y. Designing high-energy lithium-sulfur batteries. Chem. Soc. Rev. 2016, 45, 5605-5634. [CrossRef] [PubMed]

3. Myung, S.T.; Maglia, F.; Park, K.J.; Yoon, C.S.; Lamp, P.; Kim, S.J.; Sun, Y.K. Nickel-rich layered cathode materials for automotive lithium-ion batteries: Achievements and perspectives. ACS Energy Lett. 2017, 2, 196-223. [CrossRef]

4. Shi, J.; Xiao, D.; Ge, M.; Yu, X.; Chu, Y.; Huang, X.; Zhang, X.; Yin, Y.; Yang, X.; Guo, Y.; Gu, L.; Wan, L. High-capacity cathode material with high voltage for Li-ion batteries. Adv. Mater. 2018, 30, 1705575. [CrossRef] [PubMed]

5. Wang, K.X.; Li, X.H.; Chen, J.S. Surface and Interface Engineering of Electrode Materials for Lithium-Ion Batteries. Adv. Mater. 2015, 27, 527-545. [CrossRef] [PubMed]

6. Shen, S.; Xia, X.-H.; Xie, D.; Yao, Z.J.; Zhong, Y.; Zhan, J.Y.; Wang, D.H.; Wu, J.B.; Wang, X.L.; Tu, J.P. Encapsulating silicon nanoparticles into mesoporous carbon forming pomegranatestructured microspheres as a high-performance anode for lithium ion batteries. J. Mater. Chem. A 2017, 5, 11197-11203. [CrossRef] 
7. Wang, X.F.; Feng, Z.J.; Huang, J.T.; Deng, W.; Li, H.B.; Zhang, H.S.; Wen, Z.H. Graphene-decorated carbon-coated $\mathrm{LiFePO}_{4}$ nanospheres as a high-performance cathode material for lithium-ion batteries. Carbon 2018, 127, 149-157. [CrossRef]

8. Li, C.X.; Xi, Z.C.; Guo, D.X.; Chen, X.J.; Yin, L.W. Chemical immobilization effect on lithium polysulfides for lithium-sulfur batteries. Small 2018, 14, 1701986. [CrossRef] [PubMed]

9. Ding, Z.W.; Zhao, D.L.; Yao, R.R.; Li, C.; Cheng, X.W.; Hu, T. Polyaniline@spherical ordered mesoporous carbon/sulfur nanocomposites for high-performance lithium-sulfur batteries. Int. J. Hydrogen Energy 2018, 43, 10502-10510. [CrossRef]

10. $\quad$ Liang, X.Q.; Wang, J.J.; Zhang, S.Y.; Wang, L.Y.; Wang, W.F.; Li, L.Y.; Wang, H.F.; Huang, D.; Zhou, W.Z.; Guo, J. Fabrication of uniform Si-incorporated $\mathrm{SnO}_{2}$ nanoparticles on graphene sheets as advanced anode for Li-ion batteries. Appl. Surf. Sci. 2019, 476, 28-35. [CrossRef]

11. Sun, W.W.; Tao, X.C.; Du, P.P.; Wang, Y. Carbon-coated mixed-metal sulfide hierarchical structure: MOF-derived synthesis and lithium-storage performances. Chem. Eng. J. 2019, 366, 622-630. [CrossRef]

12. Lee, H.; Yanilmaz, M.; Toprakci, O.; Fu, K.; Zhang, X. A review of recent developments in membrane separators for rechargeable lithium-ion batteries. Energy Environ. Sci. 2014, 7, 3857-3886. [CrossRef]

13. Zhao, G.Y.; Tang, L.; Zhang, L.; Chen, X.; Mao, Y.C.; Sun, K.N. Well-developed capacitive-capacity of metal-organic framework derived $\mathrm{Co}_{3} \mathrm{O}_{4}$ films in Li ion battery anodes. J. Alloy. Compd. 2018, 746, 277-284. [CrossRef]

14. Li, N.; Weng, Z.; Wang, Y.; Li, F.; Cheng, H.-M.; Zhou, H. An aqueous dissolved polysulfide cathode for lithium-sulfur batteries. Energy Environ. Sci. 2014, 7, 3307-3312. [CrossRef]

15. Zhang, L.; Liang, P.; Shu, H.B.; Man, X.L.; Li, F.; Huang, J.; Dong, Q.M.; Chao, D.L. Borophene as efficient sulfur hosts for lithium-sulfur batteries: Suppressing shuttle effect and improving conductivity. J. Phys. Chem. C 2017, 121, 15549-15555. [CrossRef]

16. Yan, B.; Li, X.; Bai, Z.; Song, X.; Xiong, D.; Zhao, M.; Li, D.; Lu, S. A review of atomic layer deposition providing high performance lithium sulfur batteries. J. Power Sources 2017, 338, 34-48. [CrossRef]

17. Daniele, D.L.; Roberta, V.; Jusef, H. Lithium-ion batteries for sustainable energy storage: Recent advances towards new cell configurations. Green Chem. 2017, 19, 3442-3467.

18. He, Y.B.; Chang, Z.; Wu, S.C.; Zhou, H.S. Effective strategies for long-cycle life lithium-sulfur batteries. J. Mater. Chem. A 2018, 6, 6155-6182. [CrossRef]

19. Han, Y.; Dong, L.; Feng, J.; Li, D.; Li, X.; Liu, S. Cobalt oxide modified porous carbon anode enhancing electrochemical performance for Li-ion batteries. Electrochim. Acta 2015, 167, 246-253. [CrossRef]

20. Wang, Y.; Qu, Q.; Han, Y.; Gao, T.; Shao, J.; Zuo, Z.; Liu, W.; Shi, Q.; Zheng, H. Robust 3D nanowebs assembled from interconnected and sandwich-like $\mathrm{C} @ \mathrm{Fe}_{3} \mathrm{O}_{4} @ \mathrm{C}$ coaxial nanocables for enhanced Li-ion storage. J. Mater. Chem. A 2016, 4, 10314-10320. [CrossRef]

21. Ren, J.; Ren, R.P.; Lv, Y.K. A flexible 3D graphene@CNT@MoS2 hybrid foam anode for high-performance lithium-ion battery. Chem. Eng. J. 2018, 353, 419-424. [CrossRef]

22. Huang, Z.D.; Liu, X.M.; Oh, S.W.; Zhang, B.; Ma, P.C.; Kim, J.K. Microscopically porous, interconnected single crystal $\mathrm{LiNi}_{1 / 3} \mathrm{Co}_{1 / 3} \mathrm{Mn}_{1 / 3} \mathrm{O}_{2}$ cathode material for Lithium ion batteries. J. Mater. Chem. 2011, 21, 10777-10784. [CrossRef]

23. Chen, R.; Zhao, T.; Lu, J.; Wu, F.; Li, L.; Chen, J.; Tan, G.; Ye, Y.; Amine, K. Graphene-based three-dimensional hierarchical sandwich-type architecture for high-performance Li/S batteries. Nano Lett. 2013, 13, 4642-4649. [CrossRef] [PubMed]

24. Tian, X.H.; Zhou, Y.K.; Tu, X.F.; Zhang, Z.T.; Du, G.D. Well-dispersed $\mathrm{LiFePO}_{4}$ nanoparticles anchored on a three-dimensional graphene aerogel as high-performance positive electrode materials for lithium-ion batteries. J. Power Sources 2017, 340, 40-50. [CrossRef]

25. Yao, M.; Okuno, K.; Iwaki, T.; Kato, M.; Tanase, S.; Emura, K.; Sakai, T. $\mathrm{LiFePO}_{4}$-based electrode using micro-porous current collector for high power lithium ion battery. J. Power Sources 2007, 173, 545-549. [CrossRef]

26. Du, Y.H.; Tang, Y.F.; Huang, F.Q.; Chang, C.K. Preparation of three-dimensional free-standing nano- $\mathrm{LiFePO}_{4}$ / graphene composite for high performance lithium ion battery. RSC Adv. 2016, 6, 52279-52283. [CrossRef] 
27. Fu, F.; Tang, J.Y.; Yao, Y.Z.; Shao, M.H. Hollow Porous Hierarchical-Structured $0.5 \mathrm{Li}_{2} \mathrm{MnO}_{3} \cdot 0.5 \mathrm{LiMn}_{0.4}$ $\mathrm{Co}_{0.3} \mathrm{Ni}_{0.3} \mathrm{O}_{2}$ as a High-Performance Cathode Material for Lithium-Ion Batteries. ACS Appl. Mater. Interfaces 2016, 8, 25654-25659. [CrossRef] [PubMed]

28. Xu, J.T.; Chou, S.L.; Zhou, C.F.; Gu, Q.F.; Liu, H.K.; Dou, S.X. Three-dimensional-network $\mathrm{Li}_{3} \mathrm{~V}_{2}\left(\mathrm{PO}_{4}\right)_{3} / \mathrm{C}$ composite as high rate lithium ion battery cathode material and its compatibility with ionic liquid electrolytes. J. Power Sources 2014, 246, 124-131. [CrossRef]

29. Cui, K.; Li, Y.K. Monoclinic $\mathrm{Li}_{3} \mathrm{~V}_{2}\left(\mathrm{PO}_{4}\right)_{3} / \mathrm{C}$ nanocrystals co-modified with graphene nanosheets and carbon nanotubes as a three-dimensional-network cathode material for rechargeable lithium-ion batteries. RSC Adv. 2016, 6, 8431-8439. [CrossRef]

30. Chao, D.; Xia, X.; Liu, J.; Fan, Z.; Ng, C.F.; Lin, J.; Zhang, H.; Shen, Z.X.; Fan, H.J. Lithium-Ion Batteries: $\mathrm{A}_{2} \mathrm{O}_{5}$ /conductive-polymer core/shell nanobelt array on three-dimensional graphite foam: A high-rate, ultrastable, and freestanding cathode for lithium-ion batteries. Adv. Mater. 2014, 26, 5733. [CrossRef]

31. Gao, X.T.; Liu, Y.T.; Zhu, X.D.; Yan, D.J.; Wang, C.; Feng, Y.J.; Sun, K.N. $\mathrm{V}_{2} \mathrm{O}_{5}$ nanoparticles confined in Three-Dimensionally organized, porous Nitrogen-Doped graphene frameworks: Flexible and Free-Standing cathodes for high performance lithium storage. Carbon 2018, 140, 218-226. [CrossRef]

32. Pan, A.Q.; Wu, H.B.; Yu, L.; Zhu, T.; Lou, X.W. Synthesis of hierarchical three-dimensional vanadium oxide microstructures as high-capacity cathode materials for lithium-ion batteries. ACS Appl. Mater. Interfaces 2012, 4, 3874-3879. [CrossRef] [PubMed]

33. Guo, Q.; Sun, Z.; Gao, M.; Tan, Z.; Zhang, B.; Su, D.S. Porous V2O5-SnO2/CNTs composites as high performance cathode materials for lithium-ion batteries. J. Energy Chem. 2013, 22, 347-355. [CrossRef]

34. Liu, J.; Zheng, Q.; Goodman, M.D.; Zhu, H.; Kim, J.; Krueger, N.A.; Ning, H.; Huang, X.; Liu, J.; Terrones, M.; Braun, P.V. Graphene sandwiched mesostructured Li-ion battery electrodes. Adv. Mater. 2016, 28, 7696-7702. [CrossRef] [PubMed]

35. Park, B.G.; Kim, S.; Kim, I.-D.; Park, Y.J. Structural and electrochemical performance of three-dimensional $\mathrm{LiMn}_{2} \mathrm{O}_{4}$ thin film. J. Mater. Sci. 2010, 45, 3947-3953. [CrossRef]

36. Zhang, X.H.; Chen, D.; Liu, Y.P.; Han, W.W.; Chu, H.Q.; Rui, X.H. Integrated charge transfer in $\mathrm{Li}_{3} \mathrm{~V}_{2}\left(\mathrm{PO}_{4}\right)_{3} / \mathrm{C}$ for high-power Li-ion batteries. Int. J. Electrochem. Sci. 2017, 12, 9925-9932. [CrossRef]

37. Li, J.Z.; Luo, S.H.; Ding, X.Y.; Wang, Q.; He, P. Three-Dimensional Honeycomb-Structural LiAlO ${ }_{2}-\mathrm{Modified}$ $\mathrm{LiMnPO}_{4}$ Composite with Superior High Rate Capacity as Li-Ion Battery. ACS Appl. Mater. Interfaces 2018, 10, 10786-10795. [CrossRef] [PubMed]

38. Ragupathi, V.; Krishnaswamy, S.; Raman, S.; Panigrahi, P.; Lee, J.; Nagarajan, G.S. Enhanced electrochemical performance of $\mathrm{LiCoBO}_{3}$ cathode material for next generation Lithium-ion batteries. Appl. Surf. Sci. 2018, 449, 421-425. [CrossRef]

39. Wang, Y.; Shao, X.; Xu, H.; Xie, M.; Deng, S.; Wang, H.; Liu, J.; Yan, H. Facile synthesis of porous LiMn2O4 spheres as cathode materials for high-power lithium ion batteries. J. Power Sources 2013, 226, 140-148. [CrossRef]

40. Huang, Y.; Hou, X.; Ma, S.; Zou, X.; Wu, Y.; Hu, S.; Shao, Z.; Liu, X. Template GNL-assisted synthesis of porous $\mathrm{Li}_{1.2} \mathrm{Mn}_{0.534} \mathrm{Ni}_{0.133} \mathrm{Co}_{0.133} \mathrm{O}_{2}$ : Towards high performance cathodes for lithium ion batteries. RSC Adv. 2015, 5, 25258-25265. [CrossRef]

41. Biasi, L.D.; Lieser, G.; Drager, C.; Indris, S.; Rana, J.; Schumacher, G.; Monig, R.; Ehrenberg, H.; Binder, J.R.; Gebwein, $\mathrm{H}$. LiCaFeF 6 : A zero-strain cathode material for use in Li-ion batteries. J. Power Sources 2017, 362, 192-201. [CrossRef]

42. Baster, D.; Paziak, P.; Ziąbka, M.; Wazny, G.; Molenda, J. $\mathrm{LiNi}_{0.6} \mathrm{Co}_{0.4-z} \mathrm{Ti}_{\mathrm{z}} \mathrm{O}_{2}-\mathrm{New}$ cathode materials for Li-ion batteries. Solid State Ion. 2018, 320, 118-125. [CrossRef]

43. Doherty, C.M.; Caruso, R.A.; Smarsly, B.M.; Drummond, C.J. Colloidal crystal templating to produce hierarchically porous $\mathrm{LiFePO}_{4}$ electrode materials for high power lithium ion batteries. Chem. Mater. 2009, 21, 2895-2903. [CrossRef]

44. Tu, X.; Zhou, Y.; Song, Y. Freeze-drying synthesis of three-dimensional porous LiFePO4 modified with well-dispersed nitrogen-doped carbon nanotubes for high-performance lithium-ion batteries. Appl. Surf. Sci. 2017, 400, 329-338. [CrossRef]

45. Zhao, H.Y.; Wang, J.; Wang, G.F.; Liu, S.S.; Tan, M.; Liu, X.Q.; Komarneni, S. Facile synthesis of orthorhombic $\mathrm{LiMnO}_{2}$ nanorods by in-situ carbothermal reduction: Promising cathode material for Li ion batteries. Ceram. Int. 2017, 43, 10585-10589. [CrossRef] 
46. Duan, L.; Zhang, X.; Yue, K.; Wu, Y.; Zhuang, J.; Lu, W. Synthesis and electrochemical property of $\mathrm{LiMn}_{2} \mathrm{O}_{4}$ porous hollow nanofiber as cathode for lithium-ion batteries. Nanoscale Res. Lett. 2017, 12, 109. [CrossRef] [PubMed]

47. Jing, M.X.; Pi, Z.C.; Zhai, H.A.; Li, J.Q.; Chen, L.L.; Shen, S.Q.; Xi, X.M.; Xiao, K.S. Three-dimensional $\mathrm{Li}_{3} \mathrm{~V}_{2}\left(\mathrm{PO}_{4}\right)_{3} / \mathrm{C}$ nanowire and nanofiber hybrid membrane as a self-standing, binder-free cathode for lithium ion batteries. RSC Adv. 2016, 6, 71574-71580. [CrossRef]

48. Li, Y.H.; Xiang, K.X.; Shi, C.F.; Zhou, W.; Zhu, Y.R.; Chen, H. Frogegg-like $\mathrm{Li}_{3} \mathrm{~V}_{2}\left(\mathrm{PO}_{4}\right)_{3} /$ carbon composite with three dimensional porous structure and its improved electrochemical performance in lithium ion batteries. Mater. Lett. 2017, 204, 104-107. [CrossRef]

49. Zhu, H.; Wu, X.Z.; Zan, L.; Zhang, Y.X. Three-dimensional macroporous graphene- $\mathrm{Li}_{2} \mathrm{FeSiO}_{4}$ composite as cathode material for lithium-ion batteries with superior electrochemical performances. ACS Appl. Mater. Interfaces 2014, 6, 11724-11733. [CrossRef] [PubMed]

50. Bao, Y.H.; Zhang, X.Y.; Zhang, X.; Yang, L.; Zhang, X.Y.; Chen, H.S.; Yang, M.; Fang, D.N. Free-standing and flexible $\mathrm{LiMnTiO}_{4} /$ carbon nanotube cathodes for high performance lithium ion batteries. J. Power Sources 2016, 321, 120-125. [CrossRef]

51. Liu, J.; Yin, L.; Yang, X.Q.; Khalifah, P.G. $\mathrm{Li}_{3} \mathrm{VP}_{3} \mathrm{O}_{9} \mathrm{~N}$ as a Multielectron Redox Cathode for Li-Ion Battery. Chem. Mater. 2018, 30, 4609-4616. [CrossRef]

52. Deng, Y.L.; Mou, J.R.; Wu, H.L.; Jiang, N.; Zheng, Q.J.; Lam, K.H.; Xu, C.G.; Lin, D.M. A superior $\mathrm{Li}_{2} \mathrm{SiO}_{3}$-composited $\mathrm{LiNi}_{0.5} \mathrm{Mn}_{1.5} \mathrm{O}_{4}$ cathode for high-voltage and high-performance lithium-ion batteries. Electrochim. Acta 2017, 235, 19-31. [CrossRef]

53. Du, Y.H.; Tang, Y.F.; Chang, C.K. Enhanced electrochemical performance from $3 \mathrm{D} \mathrm{G} / \mathrm{LiFePO}_{4} / \mathrm{G}$ sandwich cathode material. J. Phys. Chem. Solids 2017, 107, 36-41. [CrossRef]

54. Wen, B.H.; Liu, J.; Chernova, N.A.; Wang, X.Y.; Janssen, Y.; Omenya, F.; Khalifah, P.G.; Whittingham, M.S. $\mathrm{Li}_{3} \mathrm{Mo}_{4} \mathrm{P}_{5} \mathrm{O}_{24}$ : A two-electron cathode for lithium-ion batteries with three-dimensional diffusion pathways. Chem. Mater. 2016, 28, 2229-2235. [CrossRef]

55. Ding, Z.P.; Liu, J.T.; Ji, R.; Zeng, X.H.; Yang, S.L.; Pan, A.Q.; Ivey, D.G.; Wei, W.F. Three-dimensionally ordered macroporous $\mathrm{Li}_{2} \mathrm{FeSiO}_{4} / \mathrm{C}$ composite as a high performance cathode for advanced lithium ion batteries. J. Power Sources 2016, 329, 297-304. [CrossRef]

56. Peng, T.; Guo, W.; Zhang, Q.; Zhang, Y.G.; Chen, M.; Wang, Y.H.; Yan, H.L.; Lu, Y.; Luo, Y.S. Uniform coaxial

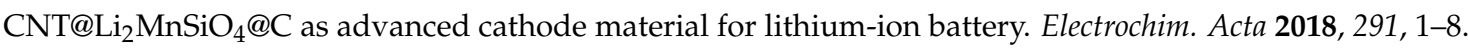
[CrossRef]

57. Yang, J.; Xu, Z.L.; Zhou, H.C.; Tang, J.P.; Sun, H.X.; Ding, J.; Zhou, X.Y. A cathode material based on the iron fluoride with an ultra-thin $\mathrm{Li}_{3} \mathrm{FeF}_{6}$ protective layer for high-capacity Li-ion batteries. J. Power Sources 2017, 363, 244-250. [CrossRef]

58. Bao, L.; Xu, G.; Sun, X.L.; Zeng, H.; Zhao, R.Y.; Yang, X.; Shen, G.; Han, G.R.; Zhou, S.X. Mono-dispersed $\mathrm{LiFePO}_{4} @ \mathrm{C}$ core-shell [001] nanorods for a high power Li-ion battery cathode. J. Alloy. Compd. 2017, 708, 685-693. [CrossRef]

59. Ludwig, J.; Marino, C.; Haering, D.; Stinner, C.; Gasteiger, H.A.; Nilges, T. Morphology-controlled microwave-assisted solvothermal synthesis of high-performance $\mathrm{LiCoPO}_{4}$ as a high-voltage cathode material for Li-ion batteries. J. Power Sources 2017, 342, 214-223. [CrossRef]

60. Zhao, J.Q.; Wang, H.; Xie, Z.Q.; Ellis, S.; Kuai, X.X.; Guo, J.; Zhu, X.; Wang, Y.; Gao, L.J. Tailorable electrochemical performance of spinel cathode materials via in-situ integrating a layered $\mathrm{Li}_{2} \mathrm{MnO}_{3}$ phase for lithium-ion batteries. J. Power Sources 2016, 333, 43-52. [CrossRef]

61. Thayumanasundaram, S.; Rangasamy, V.S.; Seo, J.W.; Locquet, J.P. A combined approach: Polyol synthesis of nanocrystalline $\mathrm{Li}_{2} \mathrm{FeSiO}_{4}$, doping multi-walled carbon nanotubes, and ionic liquid electrolyte to enhance cathode performance in Li-ion batteries. Electrochim. Acta 2017, 258, 1044-1052. [CrossRef]

62. Yang, X.J.; Wang, X.L.; Wang, K.Y.; Chang, G.L. Improved Li-storage performance of CNTs-decorated $\mathrm{LiVPO}_{4} \mathrm{~F} / \mathrm{C}$ cathode material for electrochemical energy storage. Ceram. Int. 2018, 44, 3825-3829. [CrossRef]

63. Wi, S.G.; Kim, J.W.; Lee, S.H.; Kang, J.H.; Kim, K.H.; Park, K.; Kim, K.S.; Nam, S.H.; Kim, C.J.; Park, B.W. Synthesis of $\mathrm{LiMn}_{0.8} \mathrm{Fe}_{0.2} \mathrm{PO}_{4}$ Mesocrystals for High-Performance Li-Ion Cathode Materials. Electrochim. Acta 2016, 216, 203-210. [CrossRef] 
64. Zhang, B.; Zhu, Y.S.; Yu, W.J.; Zhang, J.F.; An, C.S. Facile synthesis of carbon-encapsulated $\mathrm{LiMnBO}_{3}$ composite by the sol-gel method as a lithium-ion battery cathode material. J. Alloy. Compd. 2017, 704, 343-347. [CrossRef]

65. Jiang, C.H.; Tang, Z.L.; Wang, S.T.; Zhang, Z.T. A truncated octahedral spinel $\mathrm{LiMn}_{2} \mathrm{O}_{4}$ as high-performance cathode material for ultrafast and long-life lithium-ion batteries. J. Power Sources 2017, 357, 144-148. [CrossRef]

66. Chang, C.Y.; Huang, Z.P.; Tian, R.S.; Jiang, X.Y.; Li, C.S.; Feng, J.J. Targeted partial surface modification with nano-SiO${ }_{2} @ \mathrm{Li}_{2} \mathrm{CoPO}_{4} \mathrm{~F}$ as high-voltage cathode material for LIBs. J. Power Sources 2017, 364, 351-358. [CrossRef]

67. Yu, H.Y.; $\mathrm{Su}, \mathrm{Z}$;; Wang, L. Synthesis and electrochemical properties of $\mathrm{LiVP}_{2} \mathrm{O}_{7} / \mathrm{C}$ as novel cathode material for lithium ion batteries. Ceram. Int. 2017, 43, 17116-17120. [CrossRef]

68. Zhang, B.; Ming, L.; Tong, H.; Zhang, J.F.; Zheng, J.C.; Wang, X.W.; Li, H.; Cheng, L. Ni-doping to improve the performance of $\mathrm{LiFeBO}_{3} / \mathrm{C}$ cathode material for lithium-ion batteries. J. Alloy. Compd. 2018, 740, 382-388. [CrossRef]

69. Wang, P.P.; Xu, C.Y.; Wang, L.; Zhang, B.Y.; Zhen, L. Electrochemical behavior and structural stability of $\mathrm{LiV}_{3} \mathrm{O}_{8}$ microrods as cathode for lithium-ion batteries. Ceram. Int. 2016, 42, 18747-18755. [CrossRef]

70. Zhang, Z.F.; Chen, Z.L.; Zhang, X.H.; Wu, D.Y.; Li, J. P-doping $\mathrm{Li}_{2} \mathrm{CoSiO}_{4} / \mathrm{C}$ cathode material: A joint experimental and theoretical study. Electrochim. Acta 2018, 264, 166-172. [CrossRef]

71. Lim, S.C.; Chae, M.S.; Heo, J.W.; Hong, S.T. Electrochemical lithium intercalation chemistry of condensed molybdenum metal cluster oxide: $\mathrm{LiMo}_{4} \mathrm{O}_{6}$. J. Solid State Chem. 2017, 254, 90-95. [CrossRef]

72. Zhou, H.M.; Zhao, X.X.; Yin, C.J.; Li, J. Regeneration of $\mathrm{LiNi}_{0.5} \mathrm{Co}_{0.2} \mathrm{Mn}_{0.3} \mathrm{O}_{2}$ cathode material from spent lithium-ion batteries. Electrochim. Acta 2018, 291, 142-150. [CrossRef]

73. Lu, Y.; Luo, X.Y.; Bai, H.L.; Guo, J.M.; Xiang, M.W.; Su, C.W.; Liu, X.F.; Bai, W.; Wang, R. Investigating the enhanced kinetics of $\mathrm{LiNi}_{0.08} \mathrm{Mn}_{1.92} \mathrm{O}_{4}$ cathode material by regulating calcination temperature for long life lithium-ion battery. Vacuum 2018, 158, 223-230. [CrossRef]

74. Huang, Z.-G.; Li, J.-T.; Wang, K.; Ren, W.-F.; Lu, Y.-Q.; Deng, L.; Huang, L.; Sun, S.-G. Synthesis of $\mathrm{LiFe}_{0.4} \mathrm{Mn}_{0.4} \mathrm{Co}_{0.2} \mathrm{PO}_{4} / \mathrm{C}$ cathode material of lithium ion battery with enhanced electrochemical performance. J. Alloy. Compd. 2019, 782, 413-420. [CrossRef]

75. Zhao, H.; Shi, Y.; Xue, L.; Cheng, Y.; Hu, Z.; Liu, X. Understanding the roles of Ti on the structure and electrochemical performances of $\mathrm{Li}_{2} \mathrm{Ru}_{1-\mathrm{x}} \mathrm{Ti}_{\mathrm{x}} \mathrm{O}_{3}$ cathode materials for Li-ion batteries. J. Energy Chem. 2019, 33, 9-16. [CrossRef]

76. Zhao, J.; Liu, Y.; He, Y.; $\mathrm{Lu}, \mathrm{K} . \mathrm{Li}_{4} \mathrm{Ti}_{5} \mathrm{O}_{12}$ epitaxial coating on $\mathrm{LiNi}_{0.5} \mathrm{Mn}_{1.5} \mathrm{O}_{4}$ surface for improving the electrochemical performance through solvothermal-assisted processing. J. Alloy. Compd. 2019, 779, 978-984. [CrossRef]

77. Tang, C.; Li, B.Q.; Zhang, Q.; Zhu, L.; Wang, H.F.; Shi, J.L.; Wei, F. CaO-templated growth of hierarchical porous graphene for high-power lithium-sulfur battery applications. Adv. Funct. Mater. 2016, 26, 577-585. [CrossRef]

78. Su, D.W.; Cortie, M.; Wang, G.X. Fabrication of N-doped graphene-carbon nanotube hybrids from prussian blue for lithium-sulfur batteries. Adv. Energy Mater. 2017, 7, 1602014. [CrossRef]

79. Ummethala, R.; Fritzsche, M.; Jaumann, T.; Balach, J.; Oswald, S.; Nowak, R.; Sobczak, N.; Kaban, I.; Rümmeli, M.H.; Giebeler, L. Lightweight, free-standing 3D interconnected carbon nanotube foam as a flexible sulfur host for high performance lithium-sulfur battery cathodes. Energy Storage Mater. 2018, 10, 206-215. [CrossRef]

80. Lu, S.; Chen, Y.; Wu, X.; Wang, Z.; Li, Y. Three-dimensional sulfur/graphene multifunctional hybrid sponges for lithium-sulfur batteries with large areal mass loading. Sci. Rep. 2014, 4, 4629. [CrossRef] [PubMed]

81. Li, H.P.; Wei, Y.Q.; Ren, J.; Zhang, W.L.; Zhang, C.W.; Zhang, Y.G. Three-dimensionally ordered hierarchically porous polypyrrole loading sulfur as high-performance cathode for lithium/sulfur batteries. Polymer 2018, 137, 261-268. [CrossRef]

82. Li, C.X.; Yu, J.Y.; Xue, S.L.; Cheng, Z.H.; Sun, G.Q.; Zhang, J.; Huang, R.D.; Qu, L.T. Wood-inspired multi-channel tubular graphene network for high-performance lithium-sulfur batteries. Carbon 2018, 139, 522-530. [CrossRef] 
83. Gu, X.X.; Tong, C.J.; Wen, B.; Liu, L.M.; Lai, C.; Zhang, S.Q. Ball-milling synthesis of ZnO@sulphur/carbon nanotubes and $\mathrm{Ni}(\mathrm{OH})_{2} @$ sulphur/carbon nanotubes composites for high-performance lithium-sulphur batteries. Electrochim. Acta 2016, 196, 369-376. [CrossRef]

84. Li, Z.; Zhang, S.G.; Zhang, J.H.; Xu, M.; Tatara, R.; Dokko, K.; Watanabe, M. Three-Dimensionally Hierarchical $\mathrm{Ni} / \mathrm{Ni}_{3} \mathrm{~S}_{2} / \mathrm{S}$ Cathode for Lithium-Sulfur Battery. ACS Appl. Mater. Interfaces 2017, 9, 38477-38485. [CrossRef] [PubMed]

85. Song, Y.Z.; Zhao, W.; Kong, L.; Zhang, L.; Zhu, X.Y.; Shao, Y.L.; Ding, F.; Zhang, Q.; Sun, J.Y.; Liu, Z.F. Synchronous immobilization and conversion of polysulfides on a $\mathrm{VO}_{2}-\mathrm{VN}$ binary host targeting high sulfur load Li-S batteries. Energy Environ. Sci. 2018, 11, 2620-2630. [CrossRef]

86. Li, N.; Gan, F.Y.; Wang, P.; Chen, K.H.; Chen, S.Y.; He, X. In situ synthesis of 3D sulfur-doped graphene/sulfur as a cathode material for lithium-sulfur batteries. J. Alloy. Compd. 2018, 754, 64-71. [CrossRef]

87. Wu, R.; Chen, S.G.; Deng, J.H.; Huang, X.; Song, Y.J.; Gan, R.Y.; Wan, X.J.; Wei, Z.D. Hierarchically porous nitrogen-doped carbon as cathode for lithium-sulfur batteries. J. Energy Chem. 2018, 27, 1661-1667. [CrossRef]

88. Ji, P.H.; Shang, B.; Peng, Q.M.; Hu, X.B.; Wei, J.W. $\alpha-\mathrm{MoO}_{3}$ spheres as effective polysulfides adsorbent for high sulfur content cathode in lithium-sulfur batteries. J. Power Sources 2018, 400, 572-579. [CrossRef]

89. Wang, Y.; Huang, J.Y.; Chen, X.B.; Wang, L.; Ye, Z.Z. Powder metallurgy template growth of 3D N-doped graphene foam as binder-free cathode for high-performance lithium/sulfur battery. Carbon 2018, 137, 368-378. [CrossRef]

90. Hao, Q.Y.; Cui, G.L.; Tian, Y.; Tan, T.Z.; Zhang, Y.G. Three-dimensional S/ $\mathrm{CeO}_{2} / \mathrm{rGO}$ composites as cathode materials for lithium-sulfur batteries. Materials 2018, 11, 1720. [CrossRef] [PubMed]

91. He, J.R.; Chen, Y.F.; Lv, W.Q.; Wen, K.C.; Li, P.J.; Qi, F.; Wang, Z.G.; Zhang, W.L.; Li, Y.R.; Qin, W.; He, W.D. Highly-flexible $3 \mathrm{D} \mathrm{Li}_{2} \mathrm{~S}$ /graphene cathode for high-performance lithium sulfur batteries. J. Power Sources 2016, 327, 474-480. [CrossRef]

92. Li, C.X.; Xi, Z.C.; Dong, S.H.; Ge, X.L.; Li, Z.Q.; Wang, C.X.; Yin, L.W. CNTs/MOFs-derived carbon $/ \mathrm{Al}_{2}(\mathrm{OH})_{2.76} \mathrm{~F}_{3.24} / \mathrm{S}$ cathodes for high-performance lithium-sulfur batteries. Energy Storage Mater. 2018, 12, 341-351. [CrossRef]

93. Liang, X.; Zhang, M.G.; Kaiser, M.R.; Gao, X.W.; Konstantinov, K.; Tandiono, R.; Wang, Z.X.; Liu, H.K.; Dou, S.X.; Wang, J.Z. Split-half-tubular polypyrrole@sulfur@polypyrrole composite with a novel three-layer-3D structure as cathode for lithium/sulfur batteries. Nano Energy 2015, 11, 587-599. [CrossRef]

94. Gong, Y.; Fu, C.P.; Zhang, G.P.; Zhou, H.H.; Kuang, Y.F. Three-dimensional porous $\mathrm{C}_{3} \mathrm{~N}_{4}$ nanosheets@reduced graphene oxide network as sulfur hosts for high performance lithium-sulfur batteries. Electrochim. Acta 2017, 256, 1-9. [CrossRef]

95. Zhang, Z.A.; Li, Q.; Zhang, K.; Chen, W.; Lai, Y.Q.; Li, J. Titanium-dioxide-grafted carbon paper with immobilized sulfur as a flexible free-standing cathode for superior lithium-sulfur batteries. J. Power Sources 2015, 290, 159-167. [CrossRef]

96. Li, X.L.; Zhang, L.Y.; Ding, Z.Q.; He, Y. Ultrafine $\mathrm{Nd}_{2} \mathrm{O}_{3}$ nanoparticles doped carbon aerogel to immobilize sulfur for high performance lithium-sulfur batteries. J. Electroanal. Chem. 2017, 799, 617-624. [CrossRef]

97. Deng, N.P.; Ju, J.G.; Yan, J.; Zhou, X.H.; Qin, Q.Q.; Zhang, K.; Liang, Y.Y.; Li, Q.X.; Kang, W.M.; Cheng, B. $\mathrm{CeF}_{3}$-doped porous carbon nanofibers as sulfur immobilizers in cathode material for high-performance lithium-sulfur batteries. ACS Appl. Mater. Interfaces 2018, 10, 12626-12638. [CrossRef] [PubMed]

98. Chen, M.F.; Lu, Q.; Jiang, S.X.; Huang, C.; Wang, X.Y.; Wu, B.; Xiang, K.X.; Wu, Y.T. $\mathrm{MnO}_{2}$ nanosheets grown on the internal/external surface of $\mathrm{N}$-doped hollow porous carbon nanospheres as the sulfur host of advanced lithium-sulfur batteries. Chem. Eng. J. 2018, 335, 831-842. [CrossRef]

99. Zhang, J.; You, C.Y.; Zhang, W.H.; Wang, J.; Guo, S.H.; Yang, R.; Xu, Y.H. Conductive bridging effect of TiN nanoparticles on the electrochemical performance of TiN@CNT-S composite cathode. Electrochim. Acta 2017, 250, 159-166. [CrossRef]

100. Iqbal, A.; Ali Ghazi, Z.; Muqsit Khattak, A.; Ahmad, A. Efficient sulfur host based on $\mathrm{NiCo}_{2} \mathrm{O}_{4}$ hollow microtubes for advanced Li-S batteries. J. Solid State Chem. 2017, 256, 189-195. [CrossRef]

101. Li, X.L.; Chu, L.B.; Wang, Y.Y.; Pan, L.S. Anchoring function for polysulfide ions of ultrasmall $\mathrm{SnS}_{2}$ in hollow carbon nanospheres for high performance lithium-sulfur batteries. Mater. Sci. Eng. B 2016, 205, 46-54. [CrossRef] 
102. Li, C.C.; Liu, X.B.; Zhu, L.; Huang, R.Z.; Zhao, M.W.; Xu, L.Q.; Qian, Y.T. Conductive and polar titanium boride as a sulfur host for advanced lithium-sulfur batteries. Chem. Mater. 2018, 30, 6969-6977. [CrossRef]

103. Chen, X.; Yuan, L.X.; Hao, Z.X.; Liu, X.X.; Xiang, J.W.; Zhang, Z.R.; Huang, Y.H.; Xie, J. Free-standing $\mathrm{Mn}_{3} \mathrm{O}_{4} @ C N F / S$ paper cathodes with high sulfur loading for lithium-sulfur batteries. ACS Appl. Mater. Interfaces 2018, 10, 13406-13412. [CrossRef] [PubMed]

104. Ye, F.M.; Noh, H.J.; Lee, J.H.; Lee, H.K.; Kim, H.T. Li 2 S/Carbon nanocomposite strips from a low-temperature conversion of $\mathrm{Li}_{2} \mathrm{SO}_{4}$ as high- performance lithium-sulfur cathodes. J. Mater. Chem. A 2018, 6, 6617-6624. [CrossRef]

105. Chen, A.; Liu, W.F.; Hu, H.; Chen, T.; Ling, B.L.; Liu, K.Y. Facile preparation of ultrafine $\mathrm{Ti}_{4} \mathrm{O}_{7}$ nanoparticleembedded porous carbon for high areal capacity lithium-sulfur batteries. J. Mater. Chem. A 2018, 6, 20083-20092. [CrossRef]

106. Jin, Q.; Zhang, N.; Zhu, C.C.; Gao, H.; Zhang, X.T. Rationally designing $S / \mathrm{Ti}_{3} \mathrm{C}_{2} \mathrm{~T}_{\mathrm{x}}$ as a cathode material with an interlayer for high-rate and long-cycle lithium-sulfur batteries. Nanoscale 2018, 10, 16935-16942. [CrossRef] [PubMed]

107. He, J.R.; Chen, Y.F.; Lv, W.Q.; Wen, K.C.; Xu, C.; Zhang, W.L.; Li, Y.R.; Qin, W.; He, W.D. From metal-organic framework to $\mathrm{Li}_{2} \mathrm{~S} @ \mathrm{C}-\mathrm{Co}-\mathrm{N}$ nanoporous architecture: A high-capacity cathode for lithium-sulfur batteries. ACS Nano 2016, 10, 10981-10987. [CrossRef] [PubMed]

108. Guo, Z.Q.; Nie, H.G.; Yang, Z.; Hua, W.X.; Ruan, C.P.; Chan, D.; Ge, M.Z.; Chen, X.A.; Huang, S.M. 3D CNTs/graphene-S- $\mathrm{Al}_{3} \mathrm{Ni}_{2}$ cathodes for high-sulfur-loading and long-life lithium-sulfur batteries. Adv. Sci. 2018, 5, 1800026. [CrossRef] [PubMed]

109. Chen, Y.; Ji, X. Bamboo-like $\mathrm{Co}_{3} \mathrm{O}_{4}$ nanofiber as host materials for enhanced lithium-sulfur battery performance. J. Alloy. Compd. 2019, 777, 688-692. [CrossRef]

110. Zhang, H.; Qi, Q.; Zhang, P.; Zheng, W.; Chen, J.; Zhou, A.; Tian, W.; Zhang, W.; Sun, Z. Self-assembled 3D $\mathrm{MnO}_{2}$ nanosheets@delaminated- $\mathrm{Ti}_{3} \mathrm{C}_{2}$ aerogel as sulfur host for lithium-sulfur battery cathodes. ACS Appl. Energy Mater. 2019, 2, 705-714. [CrossRef]

111. Wu, J.; Li, S.; Yang, P.; Zhang, H.; Du, C.; Xu, J.; Song, K. S@TiO 2 nanospheres loaded on PPy matrix for enhanced lithium-sulfur batteries. J. Alloy. Compd. 2019, 783, 279-285. [CrossRef]

112. Cui, Z.; Yao, J.; Mei, T.; Zhou, S.; Hou, B.; Li, J.; Li, J.; Wang, J.; Qian, J.; Wang, X. Strong lithium polysulfides chemical trapping of $\mathrm{TiC}-\mathrm{TiO}_{2} / \mathrm{S}$ composite for long-cycle lithium-sulfur batteries. Electrochim. Acta 2019, 298, 43-51. [CrossRef]

113. Daniel, P.; Tabor, L.M.R.; Semion, K.S.; Christoph, K.; Dennis, S.; Joseph, H.M.; Shyam, D.; Muratahan, A.; Carlos, O.; Hermann, T.; et al. Accelerating the discovery of materials for clean energy in the era of smart automation. Nat. Rev. Mater. 2018, 3, 5-20.

114. Garg, A.; Peng, X.B.; Le, M.L.P.; Pareek, K.; Chind, C.M.M. Design and analysis of capacity models for lithium-ion battery. Measurement 2018, 120, 114-120. [CrossRef]

115. Li, J.; Zou, L.L.; Tian, F.; Dong, X.W.; Zou, Z.Q.; Yang, H. Parameter identification of lithium-ion batteries model to predict discharge behaviors using heuristic algorithm. J. Electrochem. Soc. 2016, 163, A1646-A1652. [CrossRef]

116. Garg, A.; Vijayaraghavan, V.; Zhang, J.; Li, S.; Liang, X.Y. Design of robust battery capacity model for electric vehicle by incorporation of uncertainties. Int. J. Energy Res. 2017, 41, 1436-1451. [CrossRef]

(C) 2019 by the authors. Licensee MDPI, Basel, Switzerland. This article is an open access article distributed under the terms and conditions of the Creative Commons Attribution (CC BY) license (http:/ / creativecommons.org/licenses/by/4.0/). 